\title{
A new chronostratigraphical and evolutionary model for La Gomera: Implications for the overall evolution of the Canarian Archipelago
}

\author{
E. Ancochea ${ }^{\mathrm{a}, *}$, F. Hernán ${ }^{\mathrm{b}}$, M.J. Huertas ${ }^{\mathrm{a}}$, J.L. Brändle ${ }^{\mathrm{a}}$, R. Herrera ${ }^{\mathrm{c}}$ \\ a Dpto. Petrología y Geoquímica, Fac. Ciencias Geológicas, Inst. Geología Económica (CSIC-Universidad Complutense), 28040 Madrid, Spain

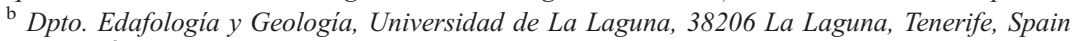 \\ c Área de Geología, ESCET, Universidad Rey Juan Carlos, 28933 Madrid, Spain
}

Received 21 October 2004; received in revised form 30 March 2006; accepted 5 April 2006

Available online 5 June 2006

\begin{abstract}
A review of the general volcano-stratigraphy and geochronology of La Gomera, one of the lesser known Canary Islands, has led to the establishment of a new evolutionary model. The oldest edifice corresponds to the submarine stage built up between 20 and $15 \mathrm{Ma}$. The construction of the Submarine Edifice was followed by an important break in the activity (about $4 \mathrm{Ma}$ ) and deep erosion of the edifice. About 10.5 Ma ago, the main present-day edifice (the Old Edifice 10.5-6.4 Ma) emerged, which was also submarine in its initial phases. Two different main stages are distinguishable. The first stage was represented by a large, some $22 \mathrm{~km}$ wide basaltic shield volcano (the Lower Old Edifice). Several lateral collapse events (Tazo and San Marcos avalanches) occurred during this time and were responsible for the removal of an important part of its northern flank. In the second growth stage (the Upper Old Edifice), the activity migrated southwards. A $25-\mathrm{km}$ wide composite volcano arose covering part of the remaining earlier shield volcano. The felsic (trachytic to phonolitic) activity occurring in two separate episodes formed a significant component of this composite volcano. Finally, one more recent large edifice (the Young Edifice) built up from 5.7 to 4 Ma. The lava flows of this younger edifice covered completely the centre and the south of the island and filled deep ravines in the north. More evolved magmas, including significant felsic magmas (the third and last felsic episode), occurred in this phase of activity.

The growth of La Gomera was long-lasting, separated by an important gap in the activity in the Middle Miocene, with no Quaternary activity at all. At the same time on Tenerife (the nearest island east of La Gomera), three large edifices grew separately: Roque del Conde, Anaga and Teno (initially three separated islands). From the available data, it is inferred that the subaerial activity started earlier in the Roque del Conde Edifice, then on La Gomera and later in Teno in the NW and Anaga in NE of Tenerife, which is the youngest of all these edifices. These facts, together with the irregular general progress of the volcanic activity, support more complex views of the genesis for the Canary Islands than the simple hotspot model.
\end{abstract}

Keywords: La Gomera; volcanic edifices; K/Ar geochronology; Canary Islands; oceanic islands; hot spot; lateral collapse; seamount

\footnotetext{
* Corresponding author.

E-mail addresses: geodec@geo.ucm.es (E. Ancochea), fhernan@ull.es (F. Hernán), huertas@geo.ucm.es (M.J. Huertas), brandle@geo.ucm.es (J.L. Brändle),rherrera@geo.ucm.es (R. Herrera).
}

\section{Introduction}

The island of La Gomera, $380 \mathrm{~km}^{2}$ in surface area, is one of the minor western islands of the Canarian Archipelago (Fig. 1). The island is round and has a diameter of $24 \mathrm{~km}$ with a maximum height of about $1500 \mathrm{~m}$ in the central area. The geological 


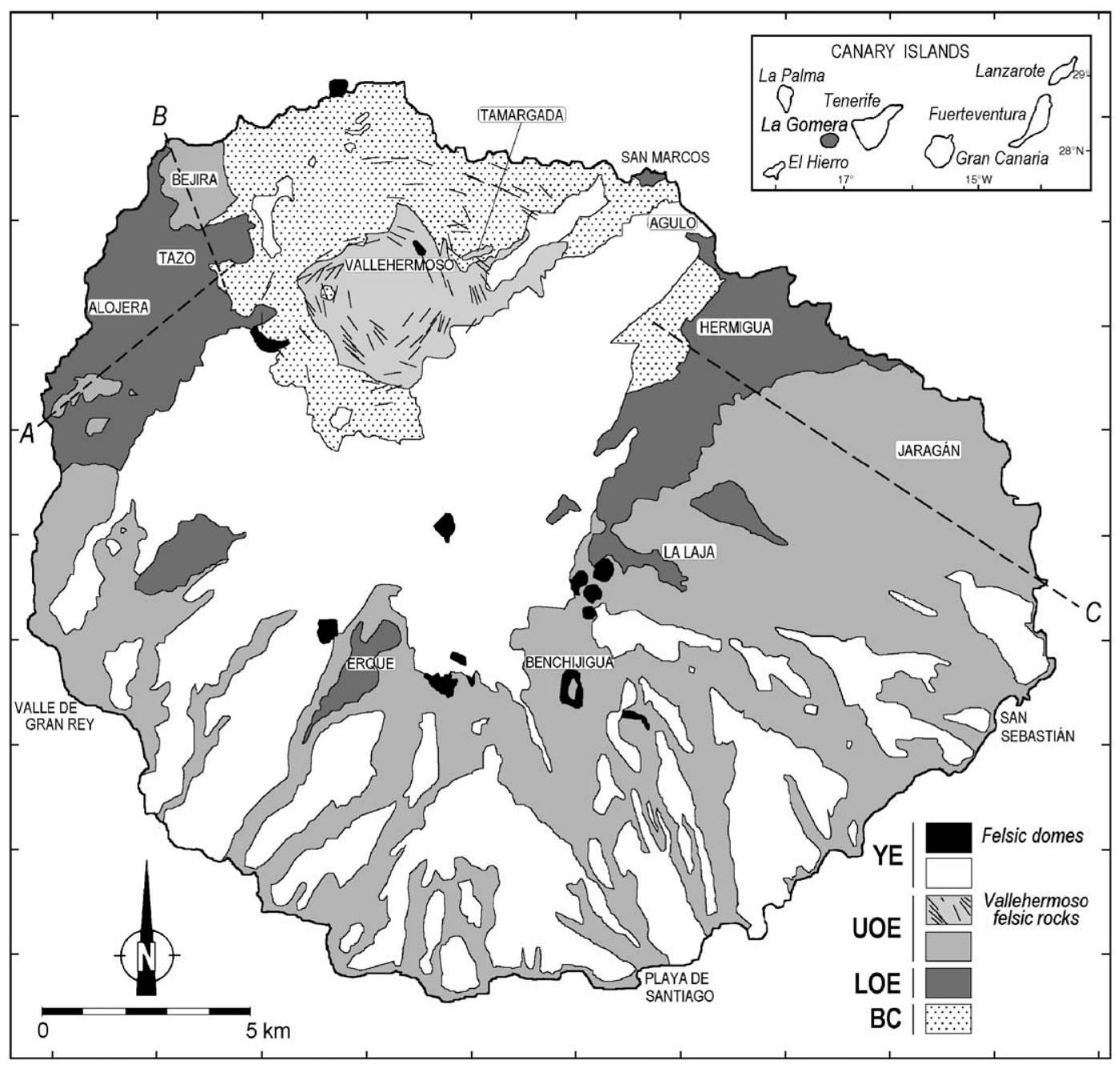

Fig. 1. Simplified geological map of main stratigraphical units of La Gomera. A, B and C cross-section in Figs. 3 and 4.

characteristics differ from those of the two other minor islands in the vicinity, La Palma and Hierro, due to the much older age of La Gomera and its lack of Quaternary activity. This makes La Gomera exceptional since it is the only island that can be considered non-active in spite of its location near the "young" end of the chain.

On the other hand, the temporal evolution of the volcanic activity on each one of the Canary Islands has always been an important key in the understanding of the archipelago, from the early models of Wilson (1973), Morgan (1971) and Anguita and Hernán (1975), to the most recent of Araña and Ortiz (1991), Hoernle and Schmincke (1993), Carracedo et al. (1998), Anguita and Hernán (2000), Geldmacher et al. (2001) and Guillou et al. (2004).

The existence of the oldest known volcanic materials on one of the easternmost islands (Fuerte- ventura) and the much younger age of the two westernmost (La Palma and Hierro) was the main initial argument to interpret the Canary Islands as a linear trace left by a mantle plume, while the African Plate moved eastwards. The model was almost immediately criticized by Anguita and Hernán (1975) who emphasized the lack of regularity in the age decrease across the chain and, very specially, the existence of anomalous several million years long gaps in the activity in some of the islands. In this context, a more precise knowledge of the volcanic history of La Gomera is required.

Due to its small size and the lack of recent activity, La Gomera is less well known in geological terms than the other islands. The first relatively modern general works that defined the main units of the island are those of Bravo (1964) and Hausen (1971). Later, Cendrero 
Table 1

Volcanostratigraphic models of La Gomera

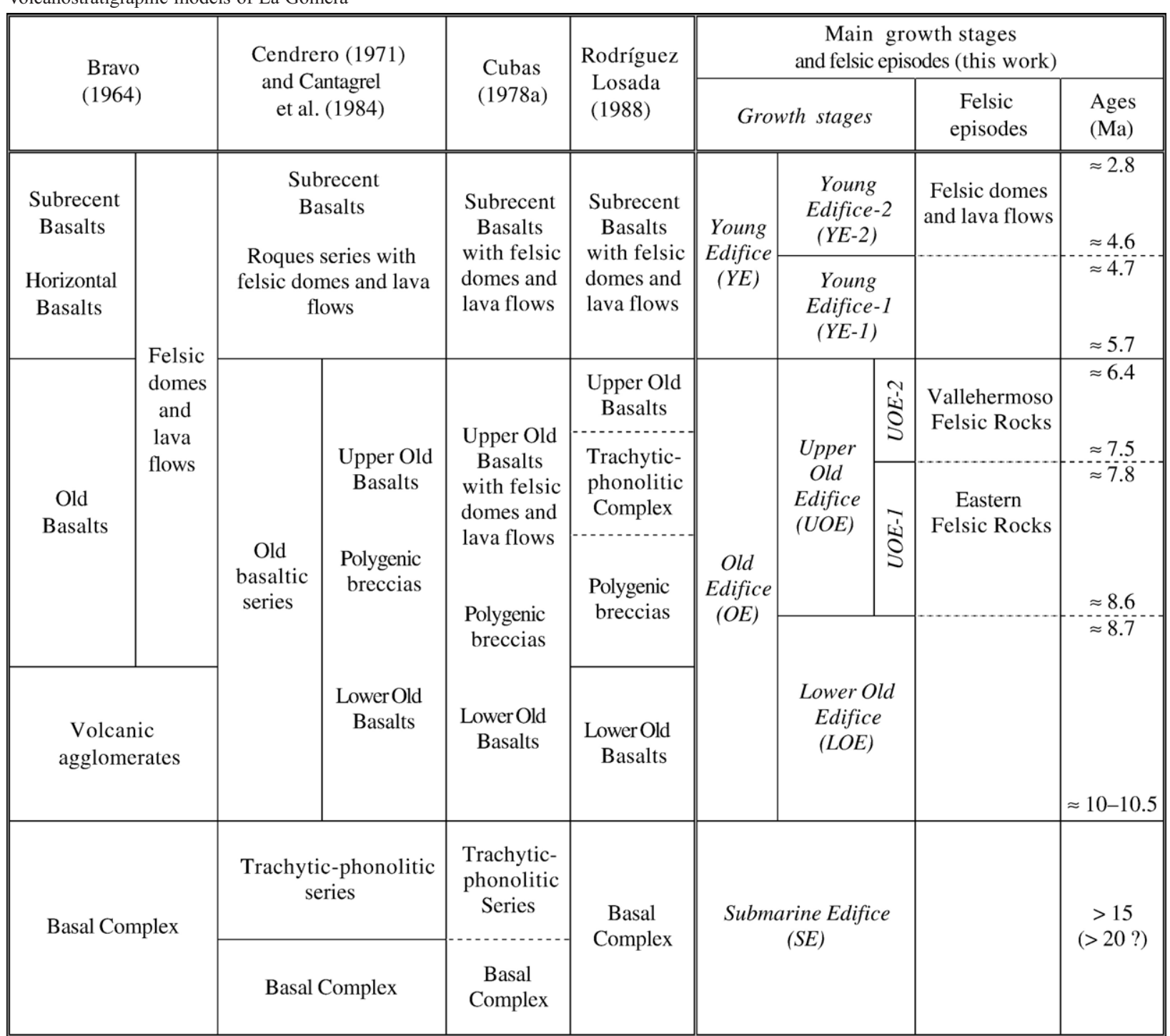

(1970, 1971) studied the oldest unit, the so-called Basal Complex (BC), Cubas (1978a,b) the felsic lava domes, a characteristic feature of the La Gomera landscape, and Rodríguez Losada $(1987,1988)$ another felsic unit known as the Trachytic-Phonolitic Complex (T-PhC). Abdel Monen et al. (1971) published the first K/Ar geochronological data, Feraud (1981) and Feraud et al. (1985) dated some dikes of different ages, and Cantagrel et al. (1984) proposed the first geochronological framework for the island based on radiometric determinations. There are only a few recent papers, the mapping works of the Instituto Geológico y Minero de España as well as the latest publication of Rodríguez
Losada and Martínez Frías (2004) about the composition of the T-PhC rocks. Some recent works by the authors of this paper have focused on the geometry and age of several felsic dike-swarms on the north sector of the island (Hernán et al., 2000; Huertas et al., 2000; Brändle et al., 2001; Cubas et al., 2002; Ancochea et al., 2003). ${ }^{1}$

The apparently similar stratigraphic models developed for La Gomera, nevertheless, show important discrepancies (Table 1) reflecting limited knowledge of

\footnotetext{
${ }^{1}$ During the review of this paper, a publication of Paris et al. (2005) has offered a different interpretation of the evolution of La Gomera.
} 
some of the geological problems of the island. These include some different aspects that are analysed in this paper: the stratigraphic position of the polygenic breccias, the significance and the stratigraphic position of the Trachytic-Phonolitic Complex, the existence of either one or more felsic intrusive episodes, and the existence of either one or more recent series.

There were some other chronostratigraphic problems that required additional radiometric testing. These include the lack of data from the Lower Old Edifice and the incongruity observed between the ages obtained from recent lava flows and dikes dated by Feraud (1981), which, as pointed out by Cantagrel et al. (1984), gave older ages than the wall-rock lava flows.

Another important aspect that causes discrepancy and crucial in the interpretation of the chain is the relative age of the "shield stage" of La Gomera compared to that of the closer most island Tenerife. A comparison of the evolution of both the islands is made in this paper.

We present here the results obtained by the systematic dating of all the volcanic units (48 new K/ Ar ages), giving special attention to those parts of the sequence more poorly sampled in previous works. The prior age data of other authors are revised and reinterpreted in order to resolve the main volcanostratigraphic problems and to propose a new more precise model for the evolution of La Gomera. The results obtained have some implications for the models proposed for the origin of the Canary Islands.

The material used for dating was represented by "whole-rock" samples of 1 or $2 \mathrm{~g}$, with particle size varying from 0.3 to $1 \mathrm{~mm}$. Phenocrysts were removed from samples (when they were too abundant) using only rock matrix for the analysis. Samples were dated by the $\mathrm{K} /$ Ar method by Mass Spec. Services (USA). Argon was extracted by fusion after degassing at moderate temperature in high vacuum and the ${ }^{38} \mathrm{Ar}$ tracer was added to the analysis using a continuous pipetting system. The analytical errors were calculated according to the method of Dalrymple and Lanphere (1969). Converted ages were calculated using the following constants: ${ }^{40} \mathrm{~K} / \mathrm{K}=1.167 \times 10^{-2}$ atoms $\%, \lambda \varepsilon=0.581 \times 10^{-10} \mathrm{yr}^{-1}$, $\lambda_{\beta}=4.962 \times 10^{-10} \mathrm{yr}^{-1},{ }^{40} \mathrm{Ar} /{ }^{36} \mathrm{Ar}$ atmosphere $=295.5$. All errors are given at the $2 \sigma$ level. To enable comparison between the results of different laboratories, two sample analyses were repeated. Roque del Cano dated by Cantagrel et al. (1984) in $4.36 \pm 0.9 \mathrm{Ma}$ is dated by Mass Spec. Services (USA) in 4.50 $\pm 0.20 \mathrm{Ma}$ (Table 5). Sample G-1 (Table 3) dated by Mass Spec. Services in $8.0 \pm 0.4 \mathrm{Ma}$ is redated by the Hungarian Science Academy in $8.0 \pm 0.3 \mathrm{Ma}$.

\section{Volcanostratigraphy and growth stages of La Gomera}

La Gomera is a single large, complex and longlived volcanic edifice within which three main growth stages are distinguishable: the Submarine Edifice (SE), the Old Edifice (OE) and the Young Edifice (YE). In turn, the subaerial stages are subdivided into: Lower Old Edifice (LOE), Upper Old Edifice (UOE), Young Edifice-1 (YE-1) and Young Edifice-2 (YE-2) (Table 1).

\section{The Submarine Edifice}

The oldest unit, the Basal Complex (BC), which crops out exclusively in the north (Fig. 1), is formed by mafic plutonic rocks, and submarine volcanics, very scarce marine sediments (fine grained, thin layered pelitic, siliceous and carbonate sediments) traversed by a dense network of mainly basic dikes (Cendrero, 1971). This unit represents mainly the submarine growth stage of the island (the Submarine Edifice) and is analogous to those existent in La Palma (Staudigel and Schmincke, 1984; De La Nuez, 1984; Staudigel et al., 1986) and Fuerteventura (Stillman et al., 1975; Le Bas et al., 1986; Ancochea et al., 1996). All the remaining islands, including Tenerife, lack the $\mathrm{BC}$, but it is thought to be underlying the subaerial units.

The BC rocks appear markedly deformed, particularly in the NW sector (Cendrero, 1971) where welldeveloped ductile deformation structures, similar to those of Fuerteventura, are seen (Fernández et al., 1997; Muñoz et al., 1997).

The dating of the BC rocks is in this case, as in the other islands, complicated because of the complex geological history of this stage composed of successive metamorphic or metasomatic processes associated with each intrusive episode. Abdel Monen et al. (1971) dated hornblendes from alkaline plutonic rocks at 19.8 and $15 \mathrm{Ma}$ (values recalculated to the constants of Steiger and Jaeger, 1977). In contrast, Cantagrel et al. (1984) obtained a much younger age $(9.1 \pm 0.3 \mathrm{Ma})$ for a hornblende bearing syenite from the same area. These authors also dated a gabbroic intrusion from a different area, cut across by only a few dikes, at $15.5 \pm 1.3 \mathrm{Ma}$. Due to the existence of thermal processes affecting the rocks, they rejected their $9.1 \mathrm{Ma}$ age and concluded that the three other age determinations most likely represented the youngest events in the basal complex. Also in their opinion, "the $20 \mathrm{Ma}$ age could be a conservative value for the onset of activity on La Gomera". We have not carried out new radiometric 
determinations in the $\mathrm{BC}$ rocks because of the difficulties mentioned above and, thus, the geochronology of this earlier stage of La Gomera is still not clearly known. However, the age of 9.1 Ma obtained for the syenite of Tamargada can be consistent in the light of new determinations carried out in rocks belonging to other felsic episodes included within the Old Edifice.

\section{The Old Edifice}

The Old Edifice (OE), the main structure on the island, reaches at present a maximum altitude of $1100 \mathrm{~m}$ near the centre and extends northwest, west, south and east on the island (Fig. 1). The $\mathrm{OE}$ rests with unconformity over the $\mathrm{BC}$, sometimes separated by sedimentary deposits that were generated when the $\mathrm{BC}$ was eroded. The present-day $\mathrm{OE}$ as a whole can be described as a pile of gently outward-dipping basaltic lava flows several hundreds of metres thick. Several thick breccia levels appear interstratified with the basaltic flows.

The OE is characteristically crossed by a large number of dikes ( 1 every $10 \mathrm{~m}$ or even less). The dike strikes show polymodal distribution in every zone, a fact that points to the existence of several dikes swarms. The lower the stratigraphic level in the OE the more abundant the dikes are and the more complex their distribution. Most dikes are basaltic in composition but felsic (trachytic to phonolitic) dikes are also frequent.

The felsic dikes have been interpreted as a complex network formed by an older Eastern Radial Swarm and a slightly younger Western Radial Swarm associated with a conical pattern, named as the Vallehermoso Cone Sheet Swarm (Fig. 3 in Ancochea et al., 2003). Other felsic rocks appear scattered in different points within the OE, especially in the eastern sector (Cubas et al., 2002).

In contrast to the clearly defined lower contact, the upper boundary of the $\mathrm{OE}$ is quite unclear. This is so because at many sites, especially in the south, the OE is found in apparent conformity with the younger units and, consequently, the identification of the boundary between both the units is very difficult and subjective. In fact, there is no agreement in this respect in the cartography available.

Based upon the different type (pahoehoe or 'aa') of lava flows, the number of dike sets and the presence of breccias, two main growth stages are distinguishable in this edifice: the Lower Old Edifice (LOE) and the Upper Old Edifice (UOE) (Table 1).

\section{The Lower Old Edifice}

The "Lower Old Basalts" and the "polygenic volcanic breccias" of previous authors (Table 1) represent the earlier stage in the construction of the OE, the Lower Old Edifice (LOE). Bravo (1964) and Cendrero (1971) recognised them in the NW sector (Alojera), but they are also observed in the NE sector (Hermigua) and at the bottom of the deepest southern "barrancos" (Fig. 2). The exposures altogether constitute a band that surrounds the BC (except in the north) and forms a pile several hundreds of metres thick of frequently ankaramitic or plagioclase-phyric pahoehoe lava flows. The lowermost flows exhibit submarine features (Cubas et al., 1994) and the upper ones are alternating with thick volcanic breccias.

Different swarms of mafic and felsic dikes characteristically traverse the LOE. There is a population of $30-40^{\circ}$ inclined mafic sills that is cut across by two younger swarms of vertical or nearly vertical mafic dikes, which vary their strike from one site to another. Vertical felsic dikes typically cut across mafic ones but the opposite cross cutting relationship is sometimes seen. The sills are always older than the vertical dikes and are absent in the UOE and in more recent units.

\subsection{Northwestern sector (Alojera sector)}

The LOE is fairly well represented in the NW sector. Here (sometimes separated by sedimentary deposits), there is a pile of south- and southwestwards-dipping thin pahoehoe lava flows several hundreds of metres thick (Fig. 3A) resting upon the $\mathrm{BC}$ and capped by individually thicker basaltic lava flows belonging to the UOE. The pahoehoe lavas are only locally alternating with some thin breccias levels. But in contrast to what has been suggested in some previous mapping (i.e. Cantagrel et al., 1984), no important breccias level separating the LOE and the UOE is observed. The contact between the LOE and the UOE lava flows is mostly seen in apparent conformity and, only locally at the cliff exposures, in slight unconformity.

The rock samples that we have dated (Tables 2 and 3) are a pahoehoe lava flow situated at a relatively low position in the series (G-3) that gives an age of $9.9 \pm$ 0.6 Ma, a sill (G-7) $9.3 \pm 0.8 \mathrm{Ma}$, two vertical basaltic dikes (G-178 and G-182) 8.1 \pm 0.5 and $8.4 \pm 0.4 \mathrm{Ma}$, respectively, and a felsic radial dike (G-1) $8.0 \pm 0.4 \mathrm{Ma}$. Cantagrel et al. (1984) also dated a dike at 10.2 $\pm 0.5 \mathrm{Ma}$, which according to their description, "sinuous disposition, and lack of vertical continuity", must belong to the 


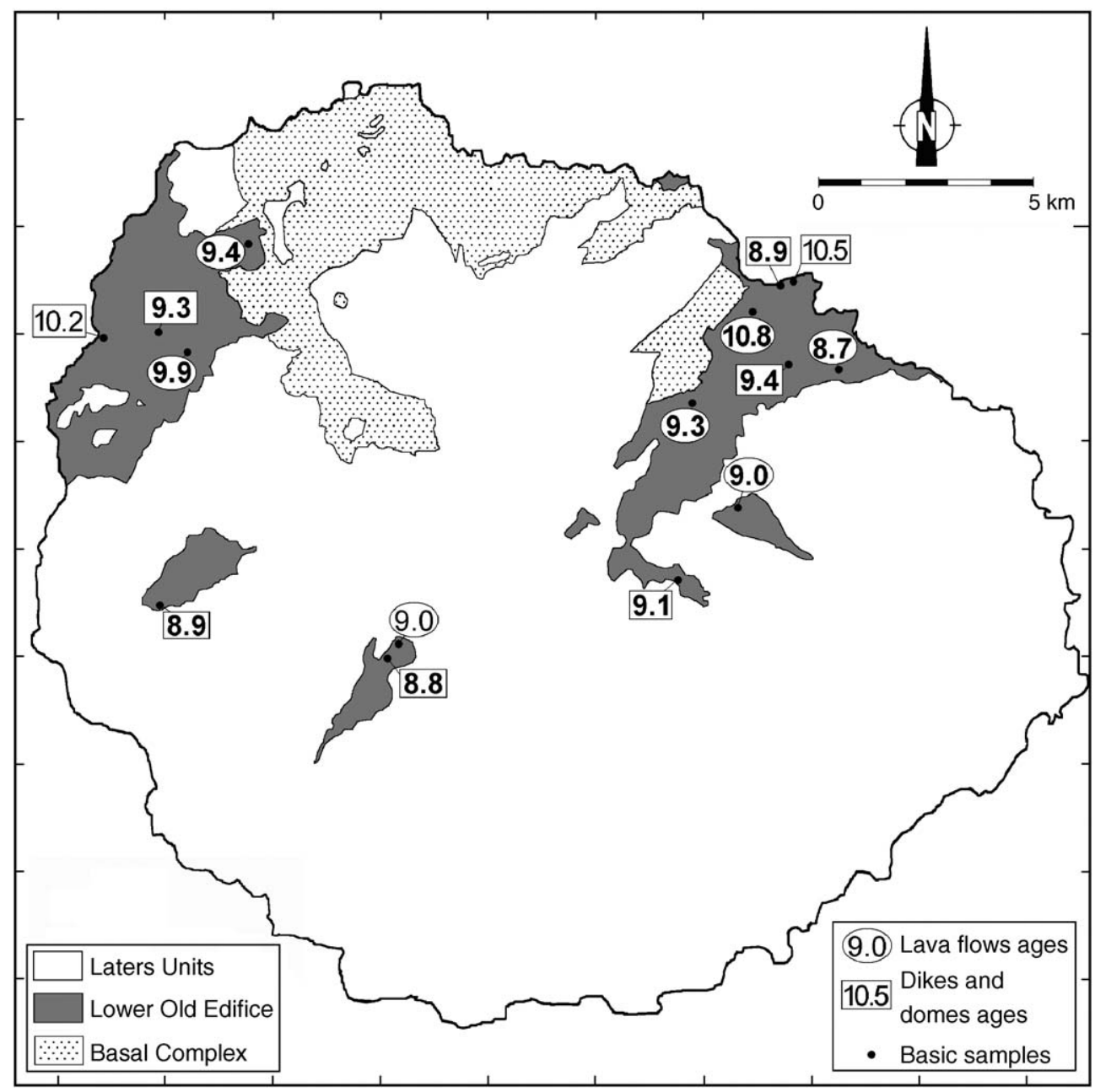

Fig. 2. Distribution of the Submarine Edifice and the Lower Old Edifice main exposures and location of the dated samples. Age in Ma: bold figures, this work; normal figures, other authors (Feraud, 1981; Cantagrel et al., 1984).

sills population. All these data support the relative chronological relationships observed in the field.

In the northernmost area within this sector, the situation is rather different (Fig. 3B). A succession of breccias (Tazo breccias) up to $150 \mathrm{~m}$ thick frequently cut by felsic and basaltic dikes rests unconformable on either the BC or the LOE lava flows. These breccias of polygenic character show fragments that are identified as remains of both the $\mathrm{BC}$ and LOE rocks. Cendrero (1971) maintained that they appear to fill a basin or channel dipping northwest. Different levels are distinguishable in the Tazo breccias, some are debris flow deposits and some others seem to be formed by sedimentary processes. A few basaltic lava flows are sporadically interstratified with the breccias.

We have obtained a new age determination (G-68; $9.4 \pm 0.5 \mathrm{Ma}$, Table 2) corresponding to a lava flow interstratified near the bottom of the Tazo breccias. One lava flow from the UOE (in Montaña Bejira) that was dated in $8.6 \pm 0.4 \mathrm{Ma}(\mathrm{G}-14)$ overlies and, consequently, postdates the Tazo breccias and the important destructive event that gave rise to them (Fig. 3B and Table 3).

\subsection{Northeastern sector (Hermigua sector)}

The LOE is also well exposed in the vicinity of Hermigua in the NE sector (Fig. 1) where a different situation is observed. Here, basaltic pahoehoe lava flows and subconformable breccias alternate in an 800-1000 $\mathrm{m}$ thick SE dipping succession. The lowermost levels show submarine features of pillow lavas, pillow breccias and hyaloclastites (Cubas et al., 1994). 

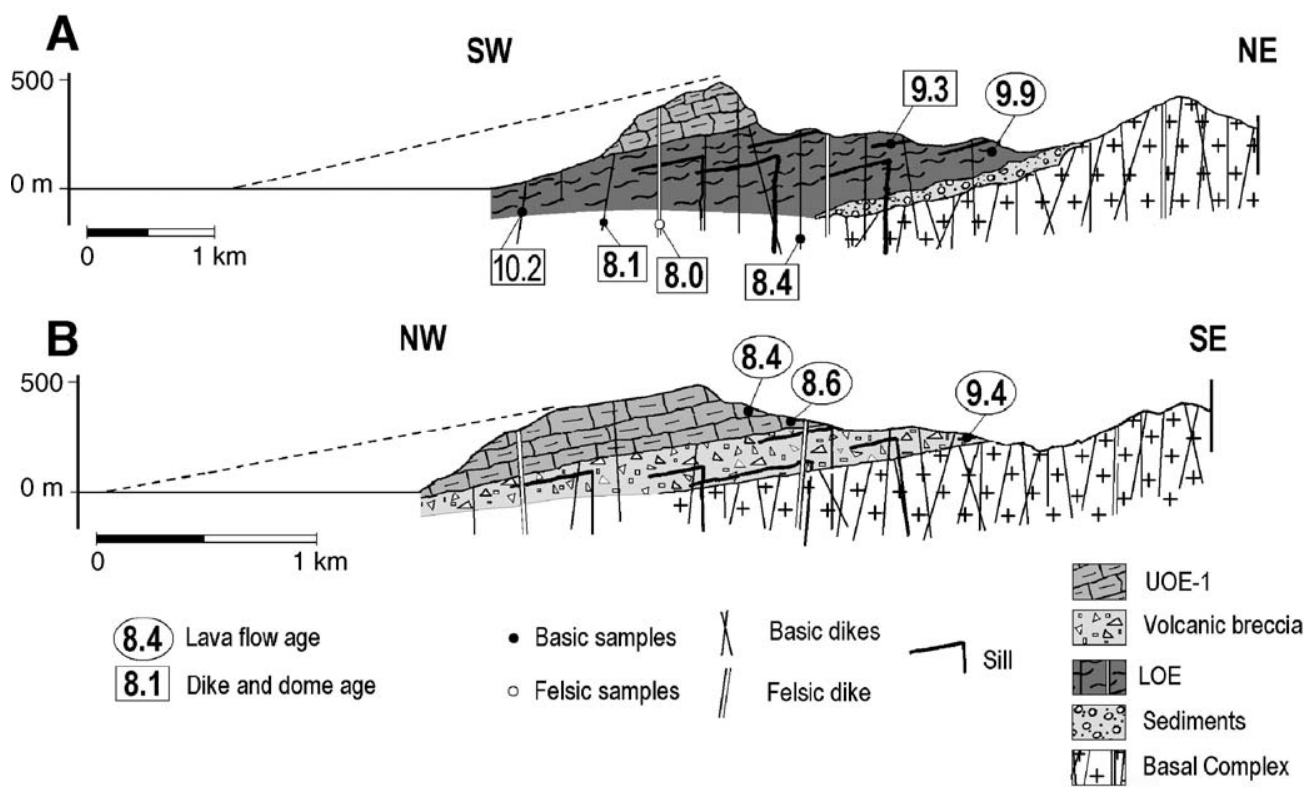

Fig. 3. Simplified cross-section and radiometric ages of the Old Edifice in Tazo-Bejira (A) and Alojera (B) sectors. See location in Fig. 1. Age symbols as in Fig. 2. Dashed line: projection of the UOE lavas to the sea level offshore from the present coastline.

The breccias levels vary in thickness from a few up to more than $100 \mathrm{~m}$. The breccias show no lateral continuity and even at some points they appear clearly as channel deposits. Their composition is variable, but exhibit common characters such as a high degree of compaction, essentially basaltic fragments, and a fine

Table 2

Radiometric ages of rock-samples from the Lower Old Edifice

\begin{tabular}{|c|c|c|c|c|c|c|c|}
\hline \multirow[t]{2}{*}{ Sample } & \multirow[t]{2}{*}{ Location } & \multicolumn{2}{|c|}{ UTM coordinates } & \multirow{2}{*}{$\begin{array}{l}{ }^{40} \mathrm{Ar}^{*} \\
\left(\mathrm{scc} / \mathrm{g} \times 10^{-5}\right)\end{array}$} & \multirow{2}{*}{$\begin{array}{l}\% \\
{ }^{40} \mathrm{Ar}^{*}\end{array}$} & \multirow{2}{*}{$\begin{array}{l}\% \\
\mathrm{~K}\end{array}$} & \multirow{2}{*}{$\begin{array}{l}\text { Age } \\
(\mathrm{Ma})\end{array}$} \\
\hline & & Longitude W & Latitude N & & & & \\
\hline & Basaltic lava flows & & & & & & \\
\hline G-30 & Hermigua, oceanitic lava flow & 286250 & 3118100 & 0.013 & 15.6 & 0.31 & $10.8 \pm 2.4$ \\
\hline G-3 & Alojera, pahoehoe lava flow & 273100 & 3117150 & 0.023 & 31.5 & 0.65 & $9.9 \pm 0.6$ \\
\hline G-68 & On the halfway Epina-Tazo, aphanitic basaltic lava flow & 274500 & 3119600 & 0.037 & 53.2 & 1.01 & $9.4 \pm 0.5$ \\
\hline G-29 & Hermigua, basaltic pillow & 284850 & 3115950 & 0.020 & 13.3 & 0.55 & $9.3 \pm 2.0$ \\
\hline Go- $33^{\mathrm{a}}$ & Halfway between Erque and Erquito, aphanitic basaltic lava flow & 277780 & 3110420 & 0.042 & 39.4 & 1.21 & $9.00 \pm 0.2$ \\
\hline G-108 & Aguajilva, picritic basaltic lava flow & 285500 & 3113490 & 0.029 & 45.4 & 0.83 & $9.0 \pm 0.5$ \\
\hline \multirow[t]{2}{*}{ G-40 } & Casas de El Palmar, olivine basaltic lava flow & 288200 & 3117200 & 0.025 & 49.5 & 0.72 & $8.7 \pm 0.4$ \\
\hline & Basaltic dikes & & & & & & \\
\hline FGo- $6^{\mathrm{b}}$ & Hermigua, basaltic dike on the road to the old dock & 287150 & 3118750 & 0.032 & 56.5 & 0.94 & $10.5 \pm 0.2$ \\
\hline Go- $57^{\mathrm{a}}$ & Alojera sea-cliff, basaltic dike & 270980 & 3117530 & 0.032 & 18.1 & 0.83 & $10.2 \pm 0.5$ \\
\hline G-22 & Hermigua, aphanitic basaltic sill & 287100 & 3116850 & 0.041 & 49.0 & 1.11 & $9.4 \pm 0.6$ \\
\hline G-7 & Alojera, pyroxenic basaltic sill & 272400 & 3117600 & 0.020 & 39.9 & 0.55 & $9.3 \pm 0.8$ \\
\hline G-146 & Barranco de Las Lajas, trachybasaltic dike & 284330 & 3111750 & 0.071 & 68.1 & 2.01 & $9.1 \pm 0.5$ \\
\hline G-160 & $\begin{array}{l}\text { Barranco de Valle de Gran Rey, Hermitage de Los Reyes olivine } \\
\text { basaltic dike }\end{array}$ & 272190 & 3111300 & 0.042 & 59.4 & 1.22 & $8.9 \pm 0.4$ \\
\hline G-145 & Hermigua, basaltic dike on the road to the old dock & 286800 & 3118750 & 0.039 & 25.5 & 1.13 & $8.9 \pm 0.9$ \\
\hline G-185 & Barranco de Erque, aphanitic basaltic dike & 277400 & 3110100 & 0.040 & 48.5 & 1.16 & $8.8 \pm 0.4$ \\
\hline
\end{tabular}

The analytical errors according to the Dalrymple and Lanphere (1969) method. Constants: ${ }^{40} \mathrm{~K} / \mathrm{K}=1.167 \times 10^{-2}$ atoms $\%, \lambda \varepsilon=0.581 \times 10^{-10} \mathrm{yr}^{-1}$, $\lambda_{\beta}=4.962 \times 10^{-10} \mathrm{yr}^{-1},{ }^{40} \mathrm{Ar} /{ }^{36} \mathrm{Ar}$ atmosphere $=295.5$.

${ }^{\text {a }}$ Cantagrel et al. (1984).

b Feraud (1981). 
Table 3

Radiometric ages of rock-samples from the Upper Old Edifice-1

\begin{tabular}{|c|c|c|c|c|c|c|c|}
\hline \multirow[t]{2}{*}{ Sample } & \multirow[t]{2}{*}{ Location } & \multicolumn{2}{|c|}{ UTM coordinates } & \multirow{2}{*}{$\begin{array}{l}{ }^{40} \mathrm{Ar}^{*} \\
\left(\mathrm{scc} / \mathrm{g} \times 10^{-5}\right)\end{array}$} & \multirow{2}{*}{$\begin{array}{l}\% \\
{ }^{40} \mathrm{Ar}^{*}\end{array}$} & \multirow{2}{*}{$\begin{array}{l}\% \\
\mathrm{~K}\end{array}$} & \multirow{2}{*}{$\begin{array}{l}\text { Age } \\
(\mathrm{Ma})\end{array}$} \\
\hline & & Longitude W & Latitude N & & & & \\
\hline & Basaltic lava flows & & & & & & \\
\hline G-14 & Bejira mountain, pyroxenic olivine basaltic lava flow & 273200 & 3119850 & 0.034 & 46.3 & 1.00 & $8.6 \pm 0.4$ \\
\hline G-16 & Bejira mountain, oceanitic lava flow & 273200 & 3120000 & 0.009 & 14.3 & 0.27 & $8.4 \pm 1.7$ \\
\hline \multirow[t]{2}{*}{ Go- $75^{\mathrm{a}}$} & Barranco de Las Lajas, ankaramitic lava flow & 285800 & 3111510 & 0.017 & 28.6 & 0.56 & $8.00 \pm 0.25$ \\
\hline & Basaltic dikes & & & & & & \\
\hline FGo- $8^{\mathrm{b}}$ & km 17 on the road Agulo-San Sebastián, basaltic dike & 283980 & 3113990 & 0.013 & 33.1 & 0.48 & $8.6 \pm 0.3$ \\
\hline G-182 & Alojera, aphanitic basaltic dike & 272400 & 3117500 & 0.042 & 60.3 & 1.27 & $8.4 \pm 0.4$ \\
\hline G-186 & Barranco de Erque, basaltic dike & 277700 & 3110300 & 0.037 & 62.3 & 1.16 & $8.2 \pm 0.4$ \\
\hline FGo- $18^{\mathrm{b}}$ & Barranco de Erquito, basaltic dike & 276650 & 3108700 & 0.036 & 57.1 & 1.35 & $8.2 \pm 0.2$ \\
\hline \multirow[t]{2}{*}{ G-178 } & Taguluche, pyroxenic-olivinic basaltic dike & 270500 & 3114900 & 0.018 & 37.2 & 0.57 & $8.1 \pm 0.5$ \\
\hline & Felsic rocks & & & & & & \\
\hline 51792 & Cuevas Blancas, trachytic dome & 290750 & 3114500 & 0.110 & 84.3 & 3.28 & $8.6 \pm 0.4$ \\
\hline 51803 & Risco Grande phonolitic dome, near Barranco de San Sebastian & 289420 & 3110770 & 0.138 & 75.1 & 4.33 & $8.2 \pm 0.4$ \\
\hline G-1 & Taguluche, phonolitic dike & 271200 & 3114470 & 0.117 & 92.5 & 3.73 & $8.0 \pm 0.4$ \\
\hline G-85 & Halfway between Vallehermoso and Barranco Claro, felsic dike & 276500 & 3118980 & 0.127 & 71.2 & 4.14 & $7.9 \pm 0.4$ \\
\hline 51828 & Lomo Majona, phonolitic dome & 290125 & 3113480 & 0.129 & 77.7 & 4.24 & $7.8 \pm 0.4$ \\
\hline
\end{tabular}

${ }^{\text {a }}$ Cantagrel et al. (1984).

b Feraud (1981).

clay groundmass often rich in pyroxene crystals. Their disposition and characteristics seem to indicate that the destructive episodes, all of them directed southeastwards, were frequent and sporadically important, but never as much as in the NW sector where the edifice was almost entirely destroyed.

As well as in the Alojera sector, two different swarms of abundant vertical basaltic dikes are identifiable while felsic ones are less frequent. There is a high number of sills (only slightly inclined), cutting across the pahoehoe lavas and the breccias. The number of sills decreases towards the top of the pile.

The UOE materials are situated on top of those of the LOE without any clearly marked discontinuity, though the boundary is fairly well identified above the uppermost breccias level. This boundary appears to coincide with the upper limit of the sills and the onset of thick characteristically black and scoriaceous basaltic lava flows.

In this LOE succession (Fig. 4), Cubas et al. (1994) obtained two rather imprecise ages for the submarine levels $(10.8 \pm 2.4 \mathrm{Ma}$ and $9.3 \pm 2.0 \mathrm{Ma})$. We have dated a sill intruding one of the lowermost breccias levels at $9.4 \pm 0.6 \mathrm{Ma}(\mathrm{G}-22)$ and two lava flows. One of the flows underlying the uppermost breccias level yields an age of $9.0 \pm 0.5 \mathrm{Ma}(\mathrm{G}-108)$ and the other one, situated above the uppermost sills (in an area where breccias levels are scarce), an age of $8.7 \pm 0.4 \mathrm{Ma}(\mathrm{G}-40)$.

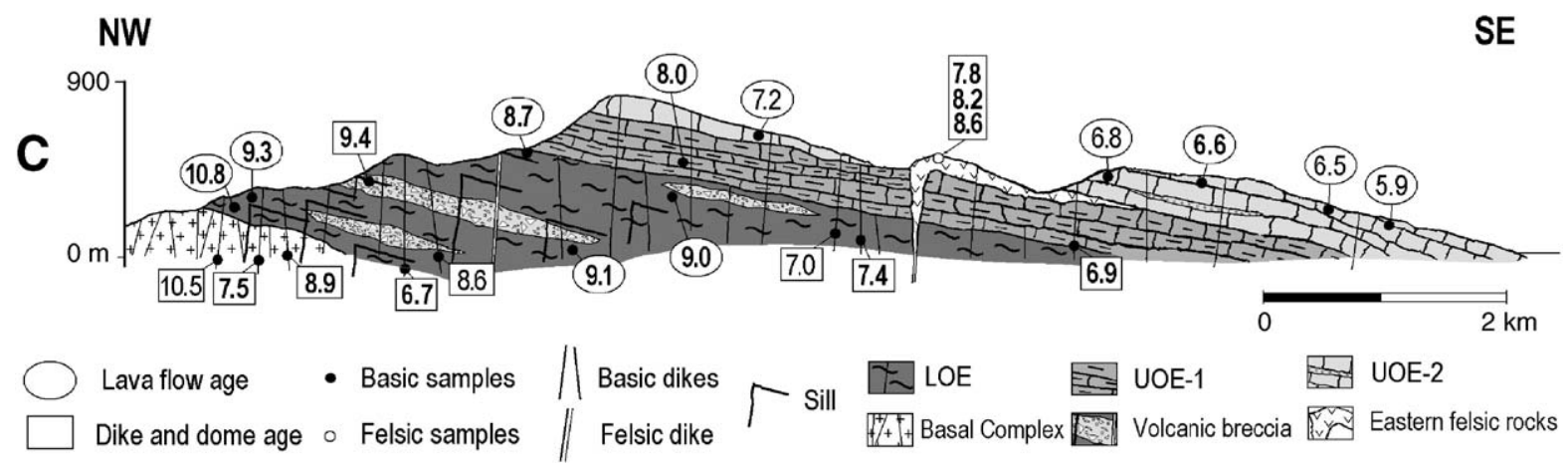

Fig. 4. Simplified eastern cross-section and radiometric ages of the Old Edifice (C). See location in Fig. 1. Age symbols as in Fig. 2. 
Feraud et al. (1985) dated dikes in this sector, one cutting across the breccias at $8.6 \pm 0.3 \mathrm{Ma}$ and another intruding the lowermost stratigraphic levels at $10.5 \pm$ 0.2 Ma. The age of this dike, the oldest obtained in this succession, corresponds to a fresh sample with more than $56 \%$ radiogenic ${ }^{40} \mathrm{Ar}$, which makes the date reliable. We also put forward here some age data from dikes intruding the succession (Figs. 2 and 4) that postdate this unit.

\subsection{Other sectors}

LOE rocks are also exposed at minor vents in the main more excavated southern ravines (Fig. 1). Thus, in Valle Gran Rey, lava flows and interbedded breccias crossed by sills and vertical dikes crop out in the innermost zone of the ravine. One of the dikes has been dated at $8.9 \pm 0.4 \mathrm{Ma}$ (G-160). Barranco de Erque, Cantagrel et al. (1984) date a lava flow at 9.0 $\pm 0.2 \mathrm{Ma}$, Feraud et al. (1985) a dike at $8.2 \pm 0.2 \mathrm{Ma}$, and the present authors date two more dikes at $8.8 \pm 0.4$ and $8.2 \pm$ $0.4 \mathrm{Ma}$ (G-185 and G-186). In La Laja, two breccias levels interbedded between pahoehoe lava flows are also exposed. We have obtained an age of $9.1 \pm 0.5 \mathrm{Ma}$ (G146) for a dike intruding the lava flows associated with these breccias. Though the existence of LOE exposures in Barranco de Benchijigua has also been mentioned (Navarro, personal communication), we have not found any evidence of LOE in that area.

Finally, near the coast in Agulo (Fig. 1), there is an important exposure of breccias (San Marcos breccias) dipping seawards and crossed by many dikes, whose characteristics and stratigraphical position (resting directly on the $\mathrm{BC}$ ) are similar to those of Tazo breccias.

\section{The Upper Old Edifice}

The Upper Old Edifice (UOE) is built mostly upon either the LOE basaltic lava flows or the debris breccias. Sometimes, especially in the NW area, the UOE rests unconformably on the LOE rocks, but may exceptionally be in direct contact with the $\mathrm{BC}$ exposures. This edifice is well exposed on the southern half of the island (Fig. 5).

The UOE is composed mainly of a $500 \mathrm{~m}$ thick succession of basalt and trachybasalt lava flows and pyroclastics referred to in classic works (Cendrero, 1971; Cubas, 1978a; Cantagrel et al., 1984; Rodríguez Losada, 1988) as "Upper Old Basalts". The radiometric age data show that the felsic activity, at least in two different episodes, was very important in the development of this edifice. This fact, together with some other data, as the distribution and abundance of dikes, allows us to distinguish two growth stages in the UOE that we name UOE-1 and UOE-2 (Table 1).

\subsection{The Upper Old Edifice-1}

The UEO-1 consists mainly of basaltic rocks. At the lowermost part of the succession, rocks are characteristically black with scoriaceous horizons, which correspond mostly to picritic and oceanitic types. Basaltic pyroclastics are more frequent than they were in the LOE, and near the top of the succession, a few thin felsic pyroclastic fall and flow deposits occur. There are numerous dikes, most of them thin, subvertical and basaltic, belonging to different swarms, and also a smaller proportion of felsic dikes.

As stated above, in the northwestern sector, the UOE1 lava flows cover directly those of the LOE with slight unconformity (Fig. 3A). In Montaña Bejira (Fig. 3B), the UOE-1 shows special characteristics since it consists of a $200 \mathrm{~m}$ thick pile of thick basaltic lava flows (Bejira Formation) resting directly on the Tazo breccias. We have dated two of these lava flows at $8.6 \pm 0.4 \mathrm{Ma}$ and 8.4 $\pm 1.7 \mathrm{Ma}$ (G-14 and G-16, Table 3). Cantagrel et al. (1984) dated a sample in the eastern sector (in La Laja some $150 \mathrm{~m}$ above the uppermost breccias) at $8.0 \pm$ $0.25 \mathrm{Ma}$ (Fig. 3C). A great number of the basaltic dikes crossing the LOE in this sector are, according to their age data $(8.6,8.4,8.2,8.2$ and 8.1, Table 3$)$, feeders of the UOE-1 edifice.

Cantagrel et al. (1984) assigned a group of felsic, essentially phonolitic plugs and very thick flows in the eastern sector to their "Roques Series" (a unit that would include all the felsic dome activity of La Gomera). However, the ages of $8.6 \pm 0.4,8.2 \pm 0.4$ and $7.8 \pm 0.4 \mathrm{Ma}$ (Table 3) obtained by us (Cubas et al., 2002) for these plugs and thick flows indicate that they represent an early felsic activity that should be ascribed to the UOE1. The felsic pyroclastic fall and flow deposits noted above are no doubt another manifestation of the same episode (the "Eastern Felsic Rocks", see Table 1). An outline of the UOE-1 succession is found in Fig. 4.

Within the felsic dike network found in the northern sector, Ancochea et al. (2003) have identified a radial swarm (ERS) that according to the age determinations ( 8.0 and $7.9 \mathrm{Ma}$ ) must have acted as a feeder for this early felsic activity.

\subsection{The Upper Old Edifice-2}

The contact relationship between the UOE-1 and the UOE-2 is not well defined. Notwithstanding, the 


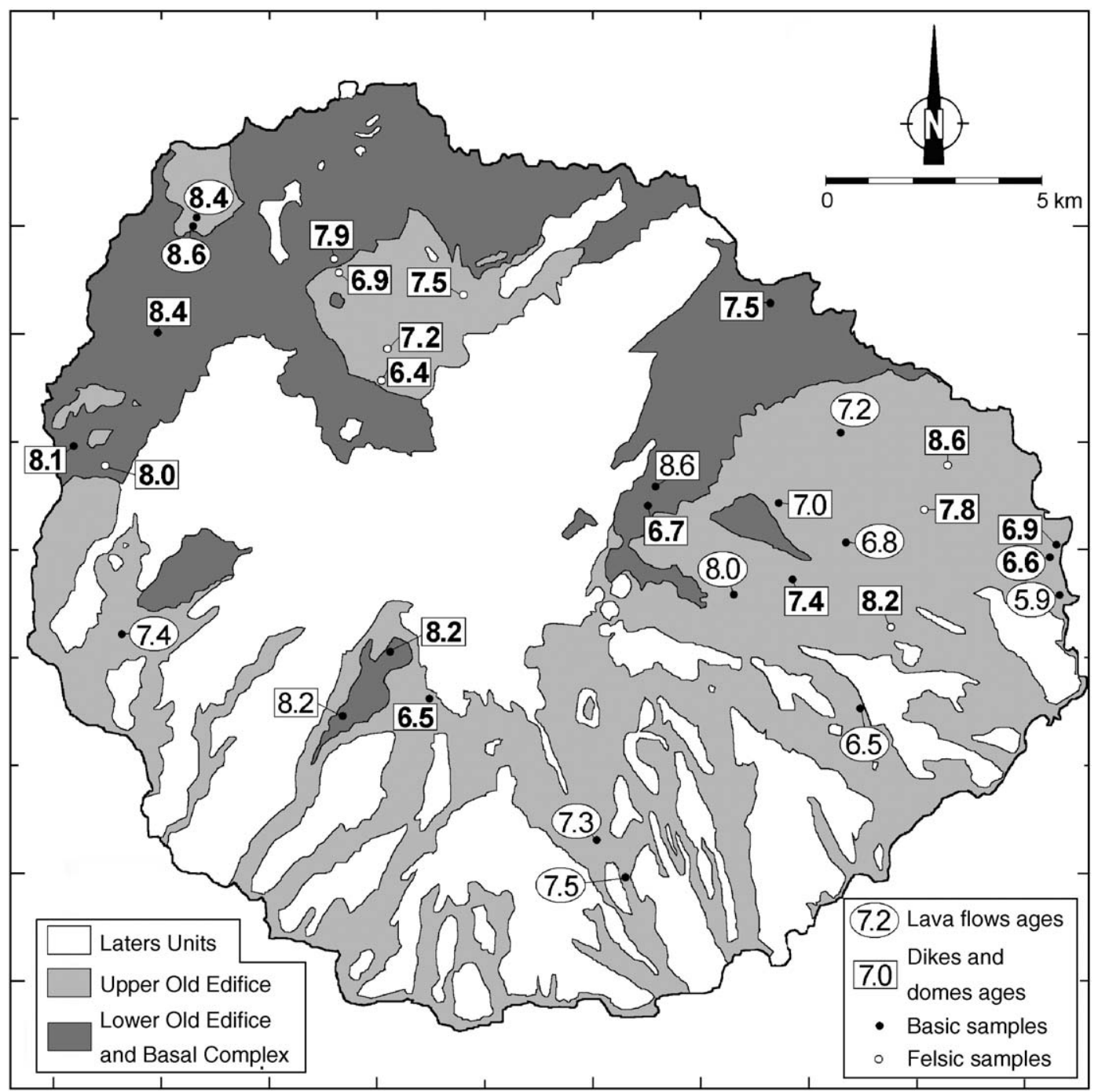

Fig. 5. Distribution of the Upper Old Edifice main exposures and location of the dated samples. Age symbols as in Fig. 2.

frequent sedimentary levels sometimes associated with felsic pyroclastics found in the eastern sector could mark the transit between both stages.

The most representative UOE-2 rocks are basalt and trachybasalt lava flows that crop out especially in the southern half of the island where they constitute the floor and the lower walls in all of the ravines (Fig. 5). Pyroclastic levels or even buried cones are frequently seen in this succession. All along the exposures in these ravines the UOE-2 rocks are capped in apparent concordance by younger basalts. Basaltic dikes are less abundant than in the previous units though two different swarms are identifiable: the first one is associated to the UOE activity, whereas the second one, constituted by thicker dikes, represents the feeding roots of a younger edifice.
In the eastern sector of the island, we can find the best exposures of the UOE-2, as well as those of the other old edifices (Fig. 4). The LOE and UOE-1 are covered here by the UOE-2 lava flows and pyroclasts succession. The real extent of these rocks is much larger than was supposed by preceding authors (i.e.: Bravo, 1964; Cantagrel et al., 1984) since the flows reach the sea in San Sebastián and all along the E and SE slopes. Cantagrel et al. (1984) dated two lava flows of this succession; both situated under the felsic pyroclasts of Jaragán, at $7.2 \pm 0.15$ and $6.8 \pm 0.15 \mathrm{Ma}$ (Table 4). We have dated a flow intercalated between the felsic pyroclasts at $6.6 \pm 0.3 \mathrm{Ma}$ (G-97). Cantagrel et al. (1984) dated two other lava flows, located farther south and higher in the succession, at $6.5 \pm 0.15$ and 5.9 $\pm 0.15 \mathrm{Ma}$. Some other age determination available from 
Table 4

Radiometric ages of rock-samples from the Upper Old Edifice-2

\begin{tabular}{|c|c|c|c|c|c|c|c|}
\hline \multirow[t]{2}{*}{ Sample } & \multirow[t]{2}{*}{ Location } & \multicolumn{2}{|c|}{ UTM coordinates } & \multirow{2}{*}{$\begin{array}{l}{ }^{40} \mathrm{Ar}^{*} \\
\left(\mathrm{scc} / \mathrm{g} \times 10^{-5}\right)\end{array}$} & \multirow{2}{*}{$\begin{array}{l}\% \\
{ }^{40} \mathrm{Ar}^{*}\end{array}$} & \multirow{2}{*}{$\begin{array}{l}\% \\
\mathrm{~K}\end{array}$} & \multirow{2}{*}{$\begin{array}{l}\text { Age } \\
(\mathrm{Ma})\end{array}$} \\
\hline & & Longitude W & Latitude $\mathrm{N}$ & & & & \\
\hline & Basaltic lava flows & & & & & & \\
\hline Go- $13^{\mathrm{a}}$ & Barranco de Santiago, basaltic lava flow & 282960 & 3104950 & 0.038 & 47.2 & 1.34 & $7.50 \pm 0.15$ \\
\hline Go- $21^{\text {a }}$ & Valle Gran Rey, basaltic lava flow & 271600 & 3110600 & 0.037 & 31.7 & 1.30 & $7.40 \pm 0.20$ \\
\hline Go- $11^{\mathrm{a}}$ & Barranco de Santiago, porphyritic basaltic lava flow & 282600 & 3105780 & 0.028 & 39.3 & 1.01 & $7.30 \pm 0.20$ \\
\hline Go- $67^{\mathrm{a}}$ & Riscos de Juel, basaltic lava flow & 288240 & 3115240 & 0.038 & 59.8 & 1.37 & $7.20 \pm 0.15$ \\
\hline Go- $71^{\mathrm{a}}$ & $\begin{array}{l}\mathrm{km} 7.8 \text { on the road from San Sebastián to Hermigua, } \\
\text { basaltic lava flow }\end{array}$ & 288370 & 3112720 & 0.037 & 54.4 & 1.41 & $6.80 \pm 0.15$ \\
\hline G-97 & Punta Llana, aphanitic basaltic lava flow & 293080 & 3112375 & 0.030 & 43.0 & 1.16 & $6.6 \pm 0.3$ \\
\hline Go- $5^{\mathrm{a}}$ & $\begin{array}{l}\text { On the road from San Sebastian to Playa de Santiago, } \\
\text { porphyritic basaltic lava flow }\end{array}$ & 288750 & 3108925 & 0.031 & 41.4 & 1.23 & $6.50 \pm 0.15$ \\
\hline \multirow[t]{2}{*}{ Go- $81^{\mathrm{a}}$} & San Sebastián, trachybasaltic lava flow & 293350 & 3111500 & 0.026 & 49.9 & 1.17 & $5.90 \pm 0.15$ \\
\hline & Basaltic dikes & & & & & & \\
\hline G-158 & Hermigua, olivinic-pyroxenic basaltic dike & 286625 & 3118250 & 0.013 & 44.9 & 0.43 & $7.5 \pm 0.4$ \\
\hline G-152 & $\begin{array}{l}\text { Barranco de Las Lajas, pyroxenic-plagioclasic } \\
\text { trachybasaltic dike }\end{array}$ & 287140 & 3111850 & 0.037 & 42.5 & 1.29 & $7.4 \pm 0.4$ \\
\hline FGo-33 ${ }^{\mathrm{b}}$ & On the road Agulo-San Sebastián, basaltic dike & 286770 & 3113240 & 0.028 & 78.6 & 1.25 & $7.0 \pm 0.1$ \\
\hline G-171 & Punta Llana, olivinic basaltic dike & 293260 & 3112550 & 0.031 & 57.4 & 1.16 & $6.9 \pm 0.3$ \\
\hline G-156 & El Rejo, plagioclasic basaltic dike & 283800 & 3113550 & 0.030 & 55.4 & 1.15 & $6.7 \pm 0.3$ \\
\hline \multirow[t]{2}{*}{ G-193 } & East of Erque, olivinic-pyroxenic basaltic dike & 278700 & 3109000 & 0.018 & 59.0 & 0.69 & $6.5 \pm 0.3$ \\
\hline & Felsic rocks & & & & & & \\
\hline 47910 & Vallehermoso, Buenavista phonolitic dome & 279440 & 3118500 & 0.114 & 20.8 & 3.89 & $7.5 \pm 0.6$ \\
\hline G-78 & Vallehermoso, El Garabato phonolitic dome & 277790 & 3117190 & 0.125 & 29.8 & 4.47 & $7.2 \pm 0.4$ \\
\hline G-84 & Halfway between Vallehermoso and Barranco Claro, felsic dike & 276500 & 3118980 & 0.118 & 35.5 & 4.40 & $6.9 \pm 0.4$ \\
\hline 47862 & Vallehermoso, La Parra phonolitic dome & 277440 & 3116310 & 0.114 & 19.2 & 4.57 & $6.4 \pm 0.5$ \\
\hline
\end{tabular}

${ }^{\text {a }}$ Cantagrel et al. (1984).

b Feraud (1981).

dikes in this area that match the age span of the UOE-2, are one of Feraud et al. (1985) $(7.0 \pm 0.1 \mathrm{Ma})$ and two new ones presented in this work $(7.4 \pm 0.4$ (G-152) and $6.9 \pm 0.3 \mathrm{Ma}(\mathrm{G}-171)$ ). Farther north, we have dated two other dikes intruding LOE at 7.5 $\pm 0.4 \mathrm{Ma}$ (G-158) and $6.7 \pm 0.3 \mathrm{Ma}(\mathrm{G}-156)$ that must also correspond to the UOE-2 (Table 4).

In the southern ravines (Fig. 5), Cantagrel et al. (1984) dated samples from three lava flows of the UOE2, two of them in Barranco de Santiago (7.5 \pm 0.15 and $7.3 \pm 0.2 \mathrm{Ma})$ and one in Valle Gran Rey $(7.4 \pm 0.2 \mathrm{Ma})$. We obtained an age of $6.5 \pm 0.3 \mathrm{Ma}$ (G-193) from a basaltic dike east of Erque.

The most important and continuous exposure of trachytic and phonolitic rocks is found in the northern sector in the vicinity of Vallehermoso (the "Vallehermoso Felsic Rocks", Table 1). These rocks essentially of hypabyssal character consist of dikes, domes and associated intrusive breccias. Previous authors (Cendrero, 1971; Rodríguez Losada, 1988) have also described pyroclastic and lava flows. Rodríguez Losada (1987) and Ancochea et al. (2003) identified and also described a cone-sheet swarm (Vallehermoso Cone
Sheet Swarm) and Ancochea et al. (2003) a radial dike swarm (Western Radial Swarm). The latter authors dated three packets of conical sheets at $7.5 \pm 0.6,7.2 \pm 0.4$ and $6.4 \pm 0.5 \mathrm{Ma}$, and a thick individual also conical sheet in $6.9 \pm 0.4 \mathrm{Ma}$. These age data show that the Vallehermoso Felsic Rocks constitute an essential part of the UOE-2 and the felsic pyroclastics appearing sporadically interstratified in the UOE-2 basaltic succession may represent the subaerial explosive manifestation of those felsic feeding channels.

\section{The Young Edifice}

The Young Edifice (YE) is made up of more than a $1000 \mathrm{~m}$ thick pile of basaltic, trachybasaltic and trachyandesitic lava flows, sporadically interstratified with basaltic pyroclasts and some felsic lava domes. These extruded felsic domes which coincide in time with the YE construction are scattered over a northsouth band on the island (Fig. 1).

In the north, the young basaltic flows rest unconformable on either the $\mathrm{BC}$ or the LOE, whereas in the western sector overlie unconformable the UOE (Fig. 1). 
Table 5

Radiometric ages of rock-samples from the Young Edifice

\begin{tabular}{|c|c|c|c|c|c|c|c|}
\hline \multirow[t]{2}{*}{ Sample } & \multirow[t]{2}{*}{ Location } & \multicolumn{2}{|c|}{ UTM coordinates } & \multirow{2}{*}{$\begin{array}{l}{ }^{40} \mathrm{Ar}^{*} \\
\left(\mathrm{scc} / \mathrm{g} \times 10^{-5}\right)\end{array}$} & \multirow{2}{*}{${ }^{\% 0} \mathrm{Ar}^{*}$} & \multirow{2}{*}{$\begin{array}{l}\% \\
\mathrm{~K}\end{array}$} & \multirow{2}{*}{$\begin{array}{l}\text { Age } \\
(\mathrm{Ma})\end{array}$} \\
\hline & & Longitude W & Latitude $\mathrm{N}$ & & & & \\
\hline & Basaltic lava flows & & & & & & \\
\hline G-167 & $\begin{array}{l}\text { Halfway between San Lorenzo and Erquito, olivinic-pyroxenic } \\
\text { basaltic lava flow }\end{array}$ & 277320 & 3108250 & 0.027 & 72.3 & 1.23 & $5.7 \pm 0.3$ \\
\hline Gm-72 & Basaltic lava flow, halfway to La Rajita & 274420 & 3105550 & 0.023 & 53.8 & 1.04 & $5.6 \pm 0.1$ \\
\hline Go- $7^{\mathrm{a}}$ & $\begin{array}{l}\text { Road from San Sebastian to Playa de Santiago, trachyandesitic } \\
\text { lava flow }\end{array}$ & 285500 & 3110000 & 0.035 & 46.6 & 1.98 & $4.60 \pm 0.10$ \\
\hline Go- $45^{\mathrm{a}}$ & Barranco de Quise, trachyandesitic lava flow & 278750 & 3104600 & 0.042 & 52.9 & 2.4 & $4.55 \pm 0.09$ \\
\hline Go- $27^{\mathrm{a}}$ & Montaña de Yerta, trachybasaltic lava flow & 283250 & 3110250 & 0.026 & 47.4 & 1.52 & $4.50 \pm 0.10$ \\
\hline Go- $1^{\mathrm{a}}$ & $\begin{array}{l}\text { Road from San Sebastian to Playa de Santiago, trachybasaltic } \\
\text { lava flow }\end{array}$ & 291700 & 3108100 & 0.035 & 38.1 & 2.04 & $4.50 \pm 0.10$ \\
\hline Go- $23^{\mathrm{a}}$ & $\begin{array}{l}\text { On the road from Arure to Valle Gran Rey, trachybasaltic } \\
\text { lava flow }\end{array}$ & 272200 & 3112000 & 0.019 & 22.1 & 1.16 & $4.40 \pm 0.20$ \\
\hline Go- $49^{\mathrm{a}}$ & $\begin{array}{l}\text { On the road from San Sebastian to Agulo, trachybasaltic } \\
\text { lava flow }\end{array}$ & 284500 & 3119950 & 0.021 & 30.2 & 1.23 & $4.35 \pm 0.15$ \\
\hline Go-53 $3^{\mathrm{a}}$ & Road to La Palmita, basaltic lava flow & 283125 & 3118825 & 0.022 & 35.6 & 1.3 & $4.30 \pm 0.10$ \\
\hline \multirow[t]{2}{*}{ Go- $17^{\mathrm{a}}$} & Viewpoint of Arure, trachybasaltic lava flow & 271550 & 3113400 & 0.014 & 43.6 & 1.38 & $2.78 \pm 0.06$ \\
\hline & Basaltic dikes & & & & & & \\
\hline G-163 & Cherelepín, trachybasaltic dike & 279250 & 3112550 & 0.024 & 49.4 & 1.13 & $5.5 \pm 0.3$ \\
\hline FGo-14 & Alajeró, basaltic dike & 282375 & 3106750 & 0.013 & 26.5 & 0.79 & $5.4 \pm 0.2$ \\
\hline G-174 & Jerduñe, trachybasaltic dike & 285050 & 3109400 & 0.031 & 70.3 & 1.48 & $5.3 \pm 0.3$ \\
\hline G-155 & El Rejo, plagioclasic basaltic dike & 284240 & 3113750 & 0.044 & 48.1 & 2.10 & $5.3 \pm 0.3$ \\
\hline FGo- $32^{\mathrm{b}}$ & Road from San Sebastian to Agulo, basaltic dike & 286750 & 3113250 & 0.021 & 71.0 & 1.25 & $5.3 \pm 0.1$ \\
\hline FGo-23b & Arure, basaltic dike & 272260 & 3113680 & 0.019 & 68.7 & 1.14 & $5.3 \pm 0.1$ \\
\hline FGo-11 & Near San Sebastian, basaltic dike & 291250 & 3108200 & 0.027 & 76.5 & 1.59 & $5.3 \pm 0.1$ \\
\hline FGo-30 ${ }^{\mathrm{b}}$ & Road from San Sebastian to Agulo, basaltic dike & 289500 & 3112600 & 0.031 & 61.9 & 1.87 & $5.2 \pm 0.1$ \\
\hline FGo- $15^{\mathrm{b}}$ & La Rajita, basaltic dike & 274700 & 3105750 & 0.028 & 75.0 & 1.66 & $5.2 \pm 0.2$ \\
\hline FGo-19 & Erquito, basaltic dike & 276700 & 3108900 & 0.022 & 37.3 & 1.32 & $5.2 \pm 0.1$ \\
\hline FGo-13 ${ }^{\mathrm{b}}$ & Road from San Sebastian to Playa de Santiago, basaltic dike & 283550 & 3105400 & 0.019 & 59.5 & 1.14 & $5.2 \pm 0.1$ \\
\hline G-175 & Jerduñe, trachybasaltic dike & 285100 & 3109500 & 0.031 & 61.9 & 1.57 & $5.1 \pm 0.3$ \\
\hline G-199 & Halfway to Benchijigua, olivinic basaltic dike & 283250 & 3108500 & 0.024 & 62.4 & 1.25 & $4.9 \pm 0.2$ \\
\hline G-187 & Barranco de Erque, trachybasaltic dike & 277700 & 3110985 & 0.021 & 55.3 & 1.13 & $4.8 \pm 0.2$ \\
\hline G-159 & On the road from Arure to Valle Gran Rey, olivinic basaltic dike & 272450 & 3112510 & 0.015 & 50.6 & 0.78 & $4.8 \pm 0.2$ \\
\hline G-192 & Imada, basaltic dike & 279500 & 3108200 & 0.032 & 42.9 & 1.73 & $4.7 \pm 0.2$ \\
\hline G-190 & Imada, basaltic dike & 279250 & 3107900 & 0.022 & 45.5 & 1.24 & $4.5 \pm 0.2$ \\
\hline G-188 & Barranco de Erque, trachybasaltic dike & 277750 & 3111100 & 0.016 & 50.5 & 0.90 & $4.4 \pm 0.2$ \\
\hline G-191 & Imada, basaltic dike & 279500 & 3107900 & 0.022 & 37.2 & 1.34 & $4.2 \pm 0.3$ \\
\hline G-148 & Barranco de La Laja, olivinic-pyroxenic basaltic dike & 284950 & 3111300 & 0.016 & 49.3 & 0.94 & $4.2 \pm 0.2$ \\
\hline \multirow[t]{2}{*}{ G-198 } & On the road from Arure to Valle Gran Rey, basaltic dike & 272600 & 3112700 & 0.015 & 45.0 & 0.98 & $4.0 \pm 0.2$ \\
\hline & Felsic rocks & & & & & & \\
\hline 48295 & Roque de Agando, trachytic dome & 282600 & 3110600 & 0.078 & 40.7 & 3.91 & $5.1 \pm 0.3$ \\
\hline Go- $59^{\mathrm{a}}$ & Road from Vallehermoso to Valle Gran Rey, phonolitic dome & 276500 & 3118300 & 0.071 & 15.8 & 3.94 & $4.63 \pm 0.27$ \\
\hline 43167 & Vallehermoso, Roque de El Cano, phonolitic dome & 278510 & 3119300 & 0.067 & 53.5 & 3.85 & $4.5 \pm 0.2$ \\
\hline Go- $63^{\mathrm{a}}$ & Vallehermoso, Roque de El Cano, phonolitic dome & 278510 & 3119300 & 0.065 & 58.2 & 3.85 & $4.36 \pm 0.09$ \\
\hline Go-39 & Fortaleza de Chipude, trachytic dome & 276375 & 3110000 & 0.047 & 59.0 & 2.79 & $4.36 \pm 0.09$ \\
\hline Go- $25^{\mathrm{a}}$ & Roque de La Zarcita, phonolitic dome & 282375 & 3111250 & 0.063 & 55.8 & 3.77 & $4.25 \pm 0.09$ \\
\hline Go- $47^{\mathrm{a}}$ & Calvario de Alajeró, trachytic lava flow & 279700 & 3105125 & 0.057 & 61.0 & 3.44 & $4.26 \pm 0.08$ \\
\hline Go- $43^{\mathrm{a}}$ & Santiago, La Caldera, trachytic lava flow & 277590 & 3102500 & 0.042 & 55.3 & 2.56 & $4.20 \pm 0.08$ \\
\hline Go- $9^{\mathrm{a}}$ & Roque Blanco, trachytic lava flow & 284100 & 3108000 & 0.061 & 59.8 & 4.01 & $3.93 \pm 0.08$ \\
\hline
\end{tabular}

\footnotetext{
${ }^{a}$ Cantagrel et al. (1984).

b Feraud (1981).
} 
In both the cases, the contact between different units is marked by a frequently thick (several tens of metres) sedimentary sequence, which is the result of erosion of the pre-existing edifices. In contrast, in the south and east of the island, the young basaltic flows rest often in apparent conformity on the older units, a fact that hinders the distinction of a boundary between units. Dikes, scarce or even non-existent in some sectors, have the same composition as the lava flows.

Bravo (1964) differentiated two young series: the "Horizontal Basalts" and the "Subrecent Basalts" (Table 1). The "Horizontal Basalts", which are older according to the author, appear unconformable with the underlying rocks in the northern, western and central sectors. The "Subrecent Basalts" dip seawards occupying an extensive area on the western and southern slopes. Simulta- neously, also according to Bravo (1964), the extrusion of the felsic domes and plugs took place.

On the contrary, Cendrero (1971) as well as other later authors (Cubas, 1978a; Cantagrel et al., 1984; Rodríguez Losada, 1988) have considered both the horizontal and the periclinal basalt flows as parts of a single series of young basaltic rocks, the "Subrecent Basalts" (Table 1). The felsic domes ("Roques Series" of Cendrero, 1971) are in their opinion prior to or contemporary with this last episode.

The previous radiometric determinations did not resolve the controversy. Thus, Feraud (1981) dated eight dikes in the YE using rock samples from different sectors and obtained a short time span from 5.4 to 5.2 Ma. Latter Cantagrel et al. (1984) dated seven flows from the YE, all of them gave ages between 4.6 and

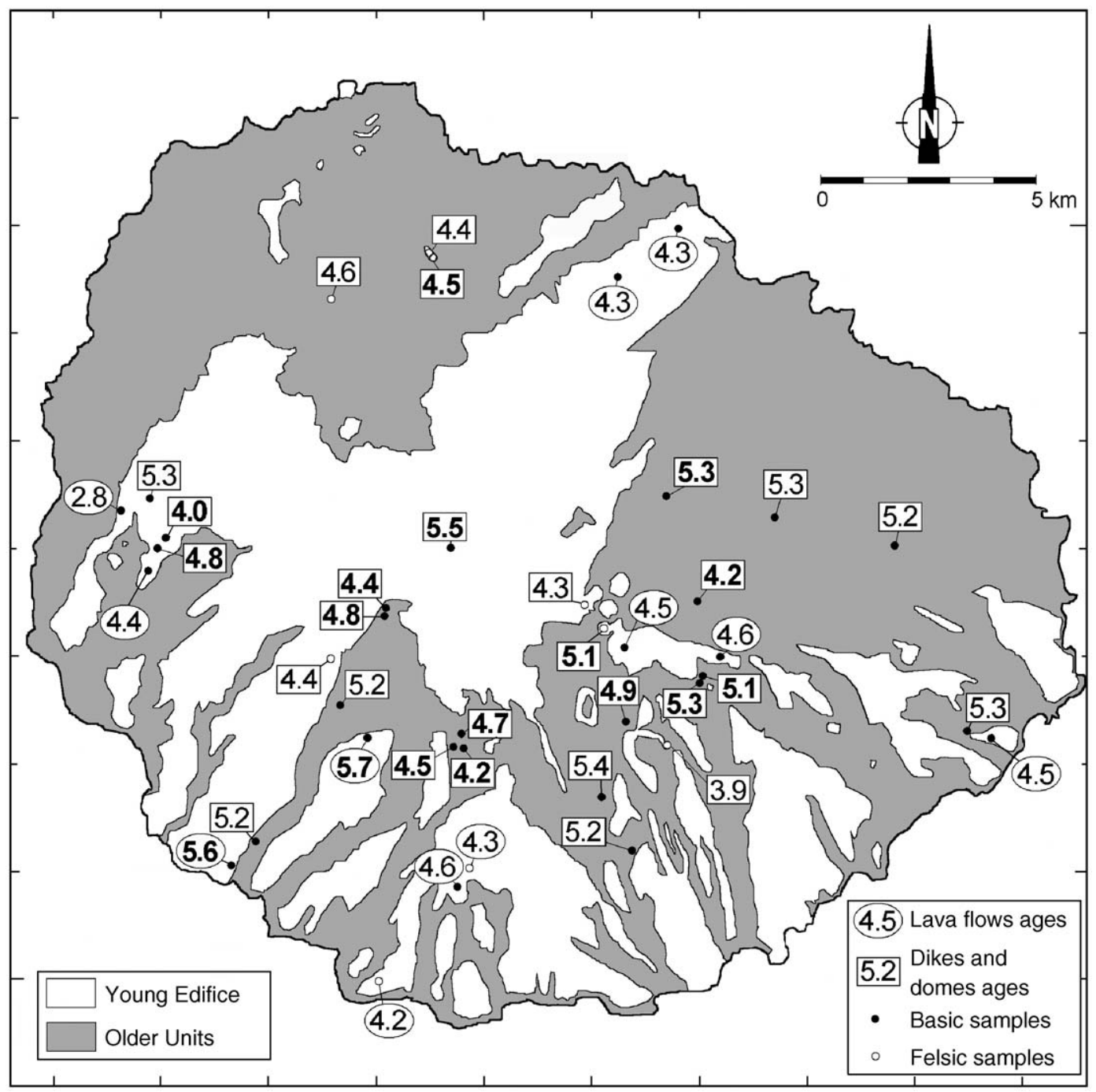

Fig. 6. Distribution of the Young Edifice main exposures and location of the dated samples. Age symbols as in Fig. 2. 
4.3 Ma (Table 5 and Fig. 6). As the lava flows yielded somewhat younger ages than the dikes, the latter authors considered that these results "could be due to a systematic bias between two different laboratories, or to the presence of a small amount of excess Ar in the dikes". This last explanation seems also to Cantagrel et al. (1984), "unlikely as all the ages are well grouped". On the other hand, in their opinion, the ages they obtained for seven felsic domes, all comprised between 4.6 and 3.9 Ma, confirmed the idea of a single episode of young volcanic activity.

In spite of the above, the detailed study of the young successions we have carried out allows us to assert that some of the local unconformities found in these successions separate units somewhat different in age. All of the flows dated by Cantagrel et al. (1984) were collected in the youngest flows of these units. Furthermore, while the horizontal successions are very seldom or almost never crossed by dikes, these can be considered normal in the southern periclinal successions, especially even in the lowermost levels where two swarms of basic dikes are recognised.

Our new age determinations correspond: firstly to a lava flow from the bottom of one of the piles crossed by dikes and clearly in unconformity with the UOE-2, dated at $5.7 \pm 0.3 \mathrm{Ma}$ (G-167), secondly to another basalt lava in the mouth of Barranco de Erque dated in 5.6 \pm $0.1 \mathrm{Ma}(\mathrm{Gm}-72)$, and thirdly to several dikes belonging to different families from different sectors (Table 5). Eight of these dikes gave ages ranging between $5.5 \mathrm{Ma}$ and $4.7 \mathrm{Ma}$ and the other five ages between 4.5 and 4.0 Ma.

In the light of these data, we could well differentiate two stages in the activity that built up the Young Edifice: the Young Edifice-1 and the Young Edifice-2 (Table 1). The first stage (YE-1) comprises an age from 5.7 to 4.7 Ma, a period of time during which the basalt and trachybasalt flows, essentially exposed in the southern sector, were emitted. This unit, which is characterised by the existence of some dikes, also appears in the central sector of the island with a high degree of weathering and covered with vegetation.

The second stage (YE-2) includes the "Horizontal Basalts" of some previous authors. The unit of horizontal basalts is characterised by an negligible inclination, absence of dikes, an abundance of evolved geochemical types and a short period of emission 4.54.3 Ma (Cantagrel et al., 1984). Unlike the idea proposed by Bravo (1964), these basalts are younger than a good part of the seaward dipping basalts. However, the unit extends southwards to the periphery and covers inclined basalt flows in apparent conformity or very slight unconformity, a fact that makes the separation of these two stages in the field, once again, extremely subjective. Lastly, a very local, isolated and residual activity took place at some points. The basalt flow dated in $2.78 \pm 0.06 \mathrm{Ma}$ by Cantagrel et al. (1984) is an example of this latest terminal activity on La Gomera. Most of the felsic plugs known as the Roques (4.63.9 Ma) extruded during this second young growth stage of the island.

\section{Evolution of the volcanic activity of La Gomera}

The new radiometric ages and the new chronostratigraphic model based on these data provide a more accurate idea of the evolution of La Gomera. The Basal Complex is the oldest unit, which lies unconformable beneath the more recent ones. The BC appears to be older than the later subaerial units and represents mainly the submarine growth stage (the Submarine Edifice) and its hypabyssal roots. To much a lesser extent than in Fuerteventura, some of the components could be coeval with the initial stages of the subaerial stages and constitute their roots as for example the syenites of Tamargada.

Even though the age data available for the $\mathrm{BC}$ are considered to be valid (instead of minimum values according to Cantagrel et al., 1984), there still exists a gap of some four million years between the most recent ages for the $\mathrm{BC}(15 \mathrm{Ma})$ and the most ancient ages for the OE (less than $11 \mathrm{Ma}$ ). The destruction and erosion of this first, entirely or almost entirely, Submarine Edifice must have occurred during this period. A question still unsolved is whether this hiatus represents a genuine gap in activity or, on the contrary, a period of intense erosion rate or even lateral failure episodes occurred as the growing seamount approached sea level. In any case, the construction of the following edifice (the Old Edifice) took place upon the remaining and relatively deep hypabyssal roots of the preceding edifice.

The reduced size of the submarine rock occurring only as screens between dikes does not enable interpretation of either the original morphology or the precise location of the edifice. Nevertheless, taking into account the existence of these exposures restricted to the northern area and the later southwards migration of the activity, it could be inferred that the Submarine Edifice was centred north of the younger subaerial ones.

The materials emitted during the early activity of the $\mathrm{OE}$ rest upon the $\mathrm{BC}$ and are often separated by sedimentary deposits that, as stated above, were formed by erosion of the Submarine Edifice. The LOE arose around 10.5-10 Ma with initial but short-lasting 


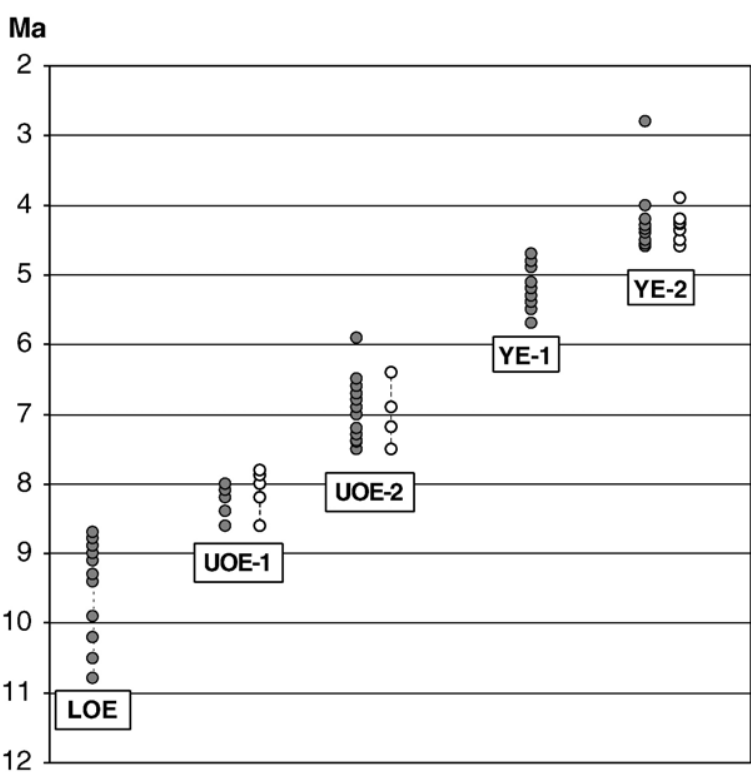

Fig. 7. Radiometric ages and temporal evolution of the different edifices on La Gomera. Felsic (white) and basic (grey) samples are distinguishable.

submarine activity (Fig. 7). The strike and dip of the lava flows, the distribution of the remaining exposures, the abundance of almost exclusively pahoehoe basalt lava flows, as well as the scarcity or almost absence of pyroclastic deposits indicate to the existence of a conventional shield volcano.

If the distribution of the LOE exposures is observed in some detail, it is possible to appreciate how the $\mathrm{W}, \mathrm{S}$ and E outcrops, stay aligned along a circle some $22 \mathrm{~km}$ in diameter (Figs. 5 and 8A). The estimated centre of the original construction would be situated in the vicinity of Vallehermoso, some $8 \mathrm{~km}$ north of the central zone of the present island. The northern rim of the emergent edifice would probably extend about $5 \mathrm{~km}$ offshore off the present northern coastline (Figs. 3 and 8A). This accounts for the shallower and less steep sea floor existent in this area. A volcanic edifice of such dimensions, if we suppose $7^{\circ}$ to $10^{\circ}$ slopes that are normal for this type of shield (Peterson and Moore, 1987), may have reached a height of 1300 to $1900 \mathrm{~m}$.

The frequent breccias associated with the lava flows in this edifice denote the important role of the destructive processes in the evolution of the shield. In the SE flank of the Old Edifice (Fig. 9A), several destructive events occurred between at least $9.4 \pm 0.6 \mathrm{Ma}$ (age of the sill G-22 crossing one of the lowermost breccias) and $9.0 \pm 0.5 \mathrm{Ma}$ (age of the lava flow G-108 situated underneath the uppermost breccias level). The successive events here were not dramatically destructive because the debris breccias appear almost conformably intercalated with the lava flows.

By contrast, the NW and NE flanks of the shield (Fig. 9A) must have been entirely destroyed in two, may be more, intense events that made all the LOE materials disappear. For this reason the remaining debris breccias rest directly over the $\mathrm{BC}$. The NW flank failure (Tazo avalanche) took place around 9.4 Ma (age of the lava flow G-68 interlayered with the breccias). The destructive landslide episode affecting the NE flank of the OE is recorded by the isolated breccias resting unconformably over the BC rocks north of Agulo (San Marcos avalanche, Fig. 9A). Both the episodes likely corresponded to a giant slide similar to those described in some other islands and identified on the Canarian sea floor (see synthesis of Krastel et al., 2001 or Masson et al., 2002). The Bejira Formation dated at $8.6 \mathrm{Ma}$ and resting directly on Tazo breccias possibly represents a remainder of the materials that subsequently filled the depression.

Most of the Canarian giant landslides episodes have been described in relationship with either the younger most islands (La Palma and Hierro) or the younger units of other islands with long-lasting activity. Less frequently mentioned are ancient giant slides like those of Gran Canaria (Schmincke and Sumita, 1998; Funck and Schmincke, 1998), Tenerife (Ibarrola et al., 1993; Watts

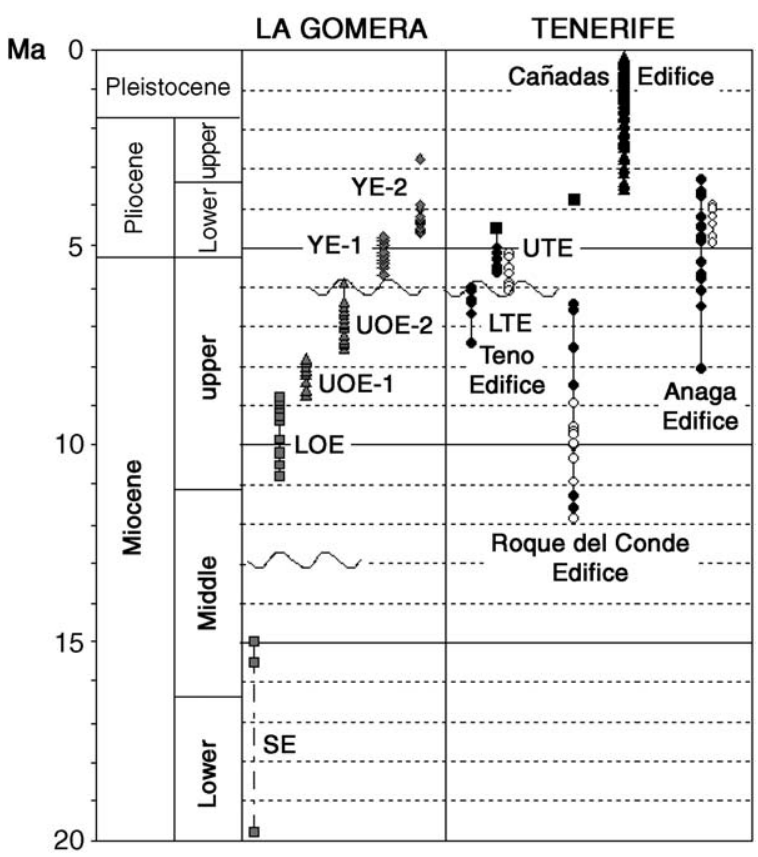

Fig. 8. Radiometric ages from the different units of La Gomera and main edifices of Tenerife. Wavy lines indicate main unconformities. Open circles correspond to radiometric ages from Guillou et al. (2004). 
and Masson, 1995; Cantagrel et al., 1999) or else those of older islands like Fuerteventura (Ancochea et al., 1996; Stillman, 1999; Krastel et al., 2001). Notwith-

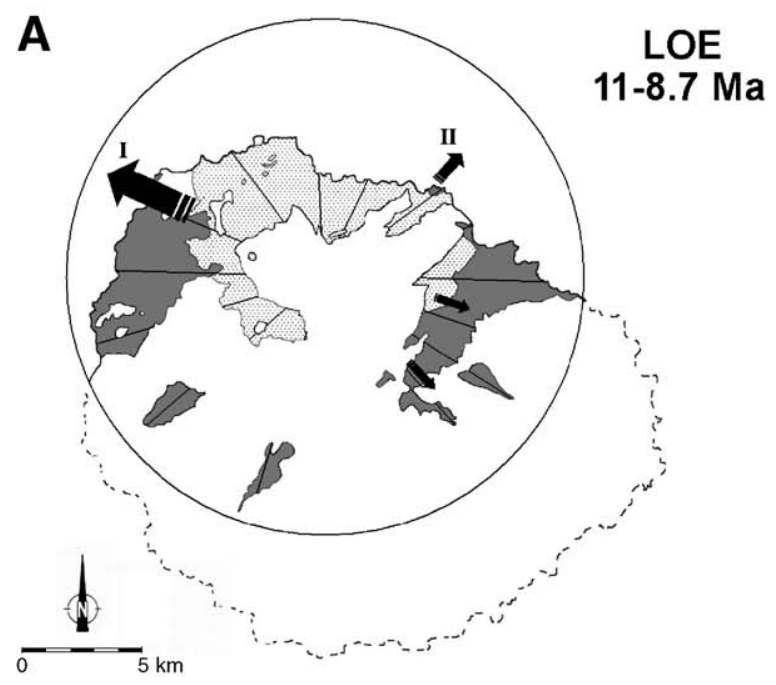

B

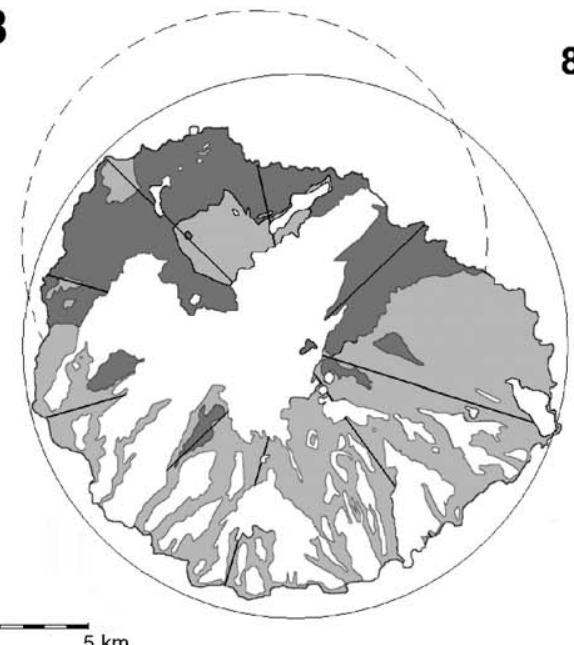

UOE 8.7-6 Ma

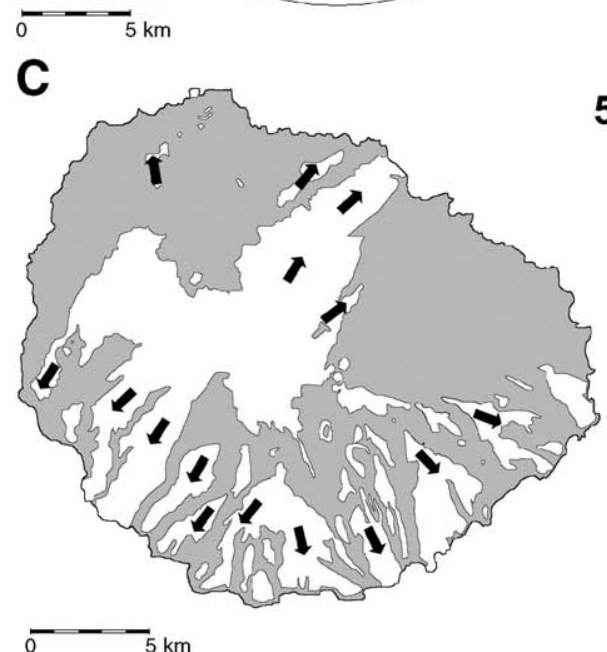

standing, no important landslide episode had been previously mentioned on La Gomera.

The UOE arose on top of the already deeply eroded LOE, at least in its northern flank where the UOE lavas overlie $\mathrm{BC}$ rocks or the LOE debris breccias (Bejira Formation). $\mathrm{E}$ and $\mathrm{W}$ the UOE lava flows pile is well exposed in several high cliffs. From this it is inferred that the edifice was originally larger in size than the present island (Fig. 3). The distribution of the UOE exposures indicates that the emissions spread out much farther south than the area occupied by the previous LOE (Fig. 9). The exposures shape a circular edifice some $25 \mathrm{~km}$ in diameter (Fig. 9B) and centred near the present centre of the island. Therefore the main activity on La Gomera shifted about $5 \mathrm{~km}$ southeast.

The hypothetical original height of this edifice can be estimated between 2000 and $2600 \mathrm{~m}$ if we suppose 9$12^{\circ}$ dipping slopes. These values are normal in volcanic edifices constituted by alternating lava flows and pyroclasts of different composition like those found on other islands of the archipelago (Peterson and Moore, 1987; Ancochea et al., 1996, 1999). Taking into account the average dip of the UOE flows makes a closer approach. The average value is about $10^{\circ}$ for example in the SE where the lava flows are better exposed and less covered by younger emissions. If we consider that this value might also represent the flank inclination, the summit would have been some $2200 \mathrm{~m}$ high in the late stage.

However, the real evolution of this edifice was probably a bit more complicated. Thus, it is not known with accuracy when and how (in a short time or progressively) the shift of the main emission centre took place or even if several main centres coexisted. Concerning the latter question, the distribution of the different felsic dike swarms appear to point to the presence of a felsic activity emission centre further north and closer to the older LOE emission centre (Ancochea et al., 2003).

The identification of two different stages of felsic activity associated with the UOE has also made it feasible to distinguish two main growth stages in this volcanic construction: the UOE-1, roughly $8.6-7.8 \mathrm{Ma}$ in age, and the UOE-2, between 7.5 Ma and 6.4 Ma (Table 1 and Fig. 7).

Fig. 9. Evolution of the subaerial volcanic activity and reconstruction of the different edifices of La Gomera. (A) Lower Old Edifice and main landslides (black arrows): I: Tazo avalanche, II: San Marcos avalanche. Colours as in Fig. 2. (B) Upper Old Edifice. Dashed circle: Lower Old Edifice. Colours as in Fig. 5. (C) Young Edifice and main flow direction of lavas (arrows). Colours as in Fig. 6. 
As we have stated above the first felsic episode (the "Eastern Felsic Rocks") comprises, on the eastern flank of the edifice (UOE), a group of felsic (dominantly phonolitic) domes, thick flows and pyroclastics and also a radial dike-swarm (the Eastern Radial Swarm). The second felsic episode (the "Vallehermoso Felsic Rocks") includes another radial swarm (the Western Radial Swarm) and the Vallehermoso Cone Sheet Swarm. The unit previously known as the Trachytic-Phonolitic Complex is only equivalent to the cores of both the Vallehermoso Cone Sheet Swarm and the associated Western Radial Swarm, but it excluded the distal facies of these two swarms. For this reason, that term should no be longer maintained.

The UOE felsic fall deposits were formerly associated (Cendrero, 1971) with the recent felsic domes and so considered it to be a part of the YE. Subsequently, all the basaltic flow piles where these felsic levels are intercalated were also erroneously thought to be much younger than they really are. The new chronological location we propose in this work implies a much lesser extent for the YE than previously supposed. The important misinterpretations present in the previous mapping should therefore be rectified in the future.

Ancochea et al. (2003) have discussed two alternative interpretations that could account for the appearance of syenites in Tamargada: (1) according to the first choice, the syenites represent an early felsic episode older than the OE felsic activity, and (2) the syenites are part of the OE felsic activity. In the first case, the age $(9.1 \pm 0.3)$ obtained by Cantagrel et al. (1984) is interpreted as a minimum value because later thermal processes affected the rocks. On the basis of the different composition shown by both (syenites and trachytic-phonolitic rocks) as well as the existence of hydrothermal alteration exclusively on the syenitic rocks, Rodríguez Losada and Martínez Frías (2004) support the first idea. Nevertheless, firstly, the more or less similar age of the Eastern Felsic Rocks (8.67.8 Ma), secondly the location of the syenites (exposed precisely where the ERS dikes converge), and thirdly the dikes crossing the syenites, which are less abundant than in the BC rocks, favour the second idea. The Tamargada syenites could be an intrusive root feeding a subaerial felsic volcano.

Rodríguez Losada and Martínez Frías (2004) also propose a collapse-caldera related to the "T-PhC". The rim of this hypothetical caldera would be located in the E, S and W high areas surrounding Vallehermoso (see Figs. 1 and 2 of these authors). Cueto et al. (1994) had already suggested the possible existence of a caldera in association with the cone-sheet complex. Nevertheless, though the presence of a cone-sheet swarm and a shallow magma chamber allow us to speculate about its relationship with some caldera-forming processes (Ancochea et al., 2003), no conclusive data about its geometry and location exist. The caldera-shaped morphology, clearly visible at present in Vallehermoso that Rodríguez Losada and Martínez Frías (2004) interpret as their caldera rim is clearly of erosional origin and much younger $(<4 \mathrm{Ma})$, because the horizontal thick flows of the YE-2 are exposed at the wall so generated.

The last volcanic edifice to form on La Gomera, the Young Edifice, never covered the entire island unlike the previous subaerial edifices. In the early phase (YE-1) lava flows erupted from the central area of the island and descended essentially south and southwestwards. It is likely that the partially eroded but still prominent OE acted locally as an obstacle that hindered the early young lavas from flowing to the north and eastwards. This activity lasted from 5.7 Ma to 4.7 Ma. During this period of roughly 1 million years, intense erosional processes, a probable new catastrophic landslide or a caldera-forming process excavated a deep depression in the north and central areas. When the next YE-2 activity took place, abundant sub-horizontal and thick individual lava flows spread all over covering a vast extension and filling deep valleys in those areas, reaching out even to the W, N and NE periphery (Fig. 9C). In this period of time, a third and last felsic episode represented by the most significant and characteristic plugs of La Gomera developed.

In summary, the post-BC volcanic activity on La Gomera has lasted at least seven million years from $11 \mathrm{Ma}$ to $4 \mathrm{Ma}$. Over this long period of time, no longlasting break in activity has been detected by the K/Ar radiometric method. By taking into account the scarce amount of age determinations between 6.4 and $5.7 \mathrm{Ma}$ (only one sample: $5.9 \mathrm{Ma}$, GO-81), we could assume a short pause in activity (less than 1 million years) occurred between the construction of the $\mathrm{OE}$ and the YE (Fig. 7). After this moment, between 4 and $2 \mathrm{Ma}$, only insignificant, very local and sporadic activity is recorded. The last 2 million years is a period of total quiescence.

\section{Temporal evolution of La Gomera in the Canarian volcanic framework}

To establish a more adequate temporal outline of the volcanic activity for the Canary Islands, a better knowledge of the onset of volcanism for each of the main edifices is required. As the onset of volcanism was 
obviously submarine, the approach usually made is to take the oldest age obtained for the shield stage, which will be acceptable only in the case of quick submarine growth. By contrast most of the data indicate that in general, as we have shown for La Gomera, the submarine and even the subaerial stage was a longlasting and complex process interrupted by several pauses.

On the other hand, in the growth of most of the Canary Islands, several independent edifices coexist. This is the case of the Eastern Canary Ridge that is the result of a chain consisting of five main edifices, three of which shape the island of Fuerteventura (the Northern, the Central and the Southern Edifices) and the two other, the island of Lanzarote (Ajaches and Famara Edifices). Two more edifices complete the southernmost part of the chain at present below sea level (Amanay and El Banquete seamounts) (Ancochea et al., 1996; Ancochea and Huertas, 2003).

\section{Comparison of the evolution of La Gomera and Tenerife}

Tenerife, the nearest island, represents another example of complex growth. On the basis of geochronological data, Ancochea et al. (1990) deduced that three separated edifices once occupied the area of the present island. The compositional data of Thirlwall et al. (2000) support this interpretation since the authors maintain that the magmas involved in each one of the old edifices of Tenerife come from different melting zones and different mantle sources. If so, during the Upper Miocene, four "islands" formed this region: La Gomera, Teno, Roque del Conde and Anaga, instead of only two as at the present time (Fig. 10).

The oldest rocks dated on Tenerife are found in the Roque del Conde Edifice (Fig. 10). This residual massif consists of a more than $1000 \mathrm{~m}$ thick pile of basalt lava flows that dip gently south and southwest. Ancochea et al. (1990) considered Roque del Conde an independent volcanic construction on the basis of $\mathrm{K} / \mathrm{Ar}$ radiometric determinations and assigned it an age between 11.6 and 6.4 Ma. By means of ${ }^{39} \mathrm{Ar} /{ }^{40} \mathrm{Ar}$ determinations, Thirlwall et al. (2000) confirmed the existence of activity 11.29 Ma and, more recently, Guillou et al. (2004) limit the age of this edifice between 11.8 and 8.9 Ma. Thus, the activity in Roque del Conde initiated somewhat earlier than the OE on La Gomera coinciding in time essentially with the development of the LOE (Fig. 8).

The Teno Edifice on Tenerife is separated from La Gomera by a narrow strait, some $25 \mathrm{~km}$ long and more than $1000 \mathrm{~m}$ deep. Due to their proximity and their similar morphological aspect and characters (deep and narrows ravines cutting thick basaltic successions), these two "islands" have often been compared. Teno is composed of two different units: the oldest one, the Lower Teno Edifice (LTE) is made of thick piles of pahoehoe lava flows and scoriae dipping seawards derived from an emission centre that must have been situated on land. Chaotic basaltic breccias, which are the

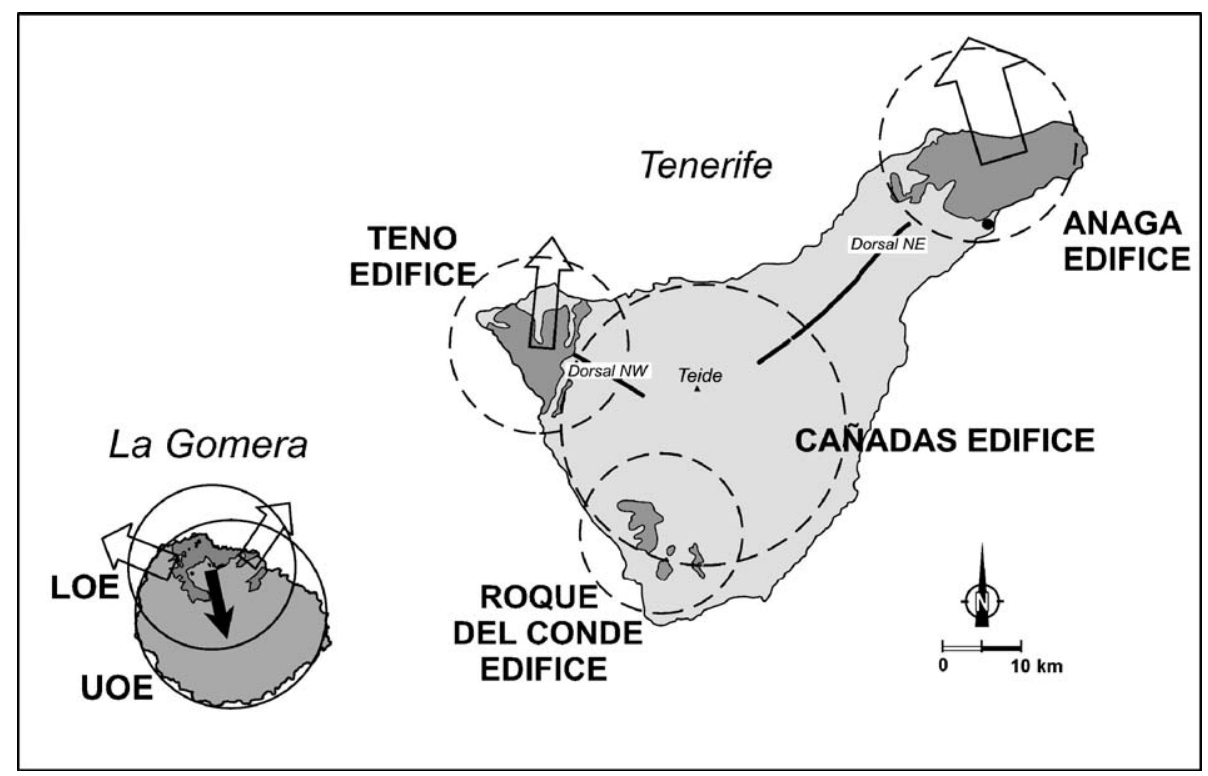

Fig. 10. Main edifices of La Gomera and Tenerife. White arrows: main landslides episodes of this island and landslides episodes occurred in the old edifices of Tenerife. Black arrow: migration of volcanic activity. 
result of one or more northwards debris-avalanche collapse events of this first edifice, cover this first succession (Cantagrel et al., 1999; Walter and Schmincke, 2002). The youngest, the Upper Teno Edifice (UTE), consists of a monotonous, some $700 \mathrm{~m}$ thick succession of nearly horizontal basaltic flows resting with unconformity over the LTE and the breccias.

A few lava flows from the LTE were dated between 7.4 Ma and 6.0 Ma and some others from the UTE between 5.7 Ma and 5 Ma (Abdel-Monem et al., 1972; Ancochea et al., 1990; Thirlwall et al., 2000; Guillou et al., 2004). The very scarce felsic activity in Teno, basically represented by a phonolitic dome is more recent (4.5 Ma). Thus, the LTE is similar in structure and age to the UOE-2 on La Gomera (Fig. 8). The possible pause in the activity (about $6 \mathrm{Ma}$ ) represented by the unconformity existing between the UOE and the YE on La Gomera broadly coincides with the giant slide episodes that dismantled the LTE on Teno. As for the UTE, this edifice also coincides in structure with the YE and even in age with its early stage, the YE-1.

The Anaga Edifice is essentially basaltic, though the felsic rocks are much more abundant than in the rest of the old edifices mentioned. The radiometric ages obtained (Abdel-Monem et al., 1972; Carracedo, 1975; Ancochea et al., 1990; Thirlwall et al., 2000; Guillou et al., 2004) oscillate mostly between 6.5 and 3.3 Ma. Even though Guillou et al. (2004) concentrate the activity exclusively between 4.9 and $3.9 \mathrm{Ma}$ (Fig. 8), the age of $8.05 \mathrm{Ma}$ obtained from lava flows in the western side of the edifice (Thirlwall et al., 2000) seems to indicate an edifice built up in two separate stages: the early one in the Upper Miocene (around 8$6 \mathrm{Ma})$ and the late one in the Lower Pliocene. The late activity that occurred in the Anaga Edifice coincides with the initiation of the Cañadas Edifice (Huertas et al., 1994; Ancochea et al., 1999), which is located between the three surrounding older edifices partially covering the Teno and Roque del Conde Edifices. Finally, the development of the western and eastern ridges of Tenerife shaped the present aspect of the island (Fig. 10). The activity of the huge Cañadas Edifice continues at present in both the ridges and in the Teide volcano.

Since the ages of the seamount stage of La Gomera and the edifices of Tenerife are still unknown, it is not possible to make an accurate comparison between all the growth stages of these islands. Nevertheless, from all the available data (Fig. 8), we can conclude that the subaerial growth of La Gomera and Roque del Conde was initiated prior to the Anaga and Teno Edifices. So that, the activity of Tenerife and La Gomera does not progress from east to west as the defenders of a hotspot origin (i.e. Guillou et al., 2004) sustain. On the contrary, the shift is just the opposite if there is any in this section of the chain.

\section{Chronological evolution of the Canarian volcanism}

If the Canarian archipelago is considered as a whole, the earliest recorded activity is represented by the submarine activity of the Basal Complex of Fuerteventura, which is Oligocene in age (Stillman et al., 1975; Robertson and Bernouilli, 1982). Sánchez Guzmán and Abad (1986) also registered materials similar in character and age in a deep drilling in Lanzarote (Fig. 11A). In the transit, Oligocene-Lower Miocene Fuerteventura proceeded with the submarine growth and initiated its emergence (Muñoz and Sagredo, 2004). In the Lower Miocene, the main old edifices of Fuerteventura had already emerged or started to emerge (Ancochea et al., 1996), while at the same time, according to the radiometric data from intrusive rocks, La Gomera should have already initiated the seamount stage (Fig. 11B).

The Middle Miocene is probably the most productive period in the volcanic history of the archipelago (Fig. 11C). The old three edifices of Fuerteventura and the Ajaches Edifice on Lanzarote reach their maximum (Coello et al., 1992) as well as the submarine Banco de la Concepción (Geldmacher et al., 2001), the Amanay Edifice and probably El Banquete Edifice (Ancochea and Huertas, 2003). The activity also reaches a maximum in Gran Canaria where the basaltic shield rises in a short period of time (McDougall and Schmincke, 1976; Bogaard et al., 1988). By contrast, there is no evidence of activity at that time in La Gomera where the Submarine Edifice would be being eroded.

In the Upper Miocene, the focus of activity changed (Fig. 11D). It moved from the southern extreme of the Eastern Canarian Ridge to the northernmost end where the Famara Edifice arises (Coello et al., 1992; Ancochea et al., 1996). On Gran Canaria, the felsic emissions keep on being active until $8 \mathrm{Ma}$ when there is a break until $3 \mathrm{Ma}$ in the Lower Pliocene (McDougall and Schmincke, 1976; Bogaard et al., 1988). The large basaltic edifices of Tenerife and La Gomera grow then coinciding with the pause on Gran Canaria.

In the Lower Pliocene, all of the five islands remained active (Fig. 11E). On Lanzarote, the activity concentrated in the Famara Edifice, whereas Fuerteventura, after a period of long quiescence (almost 


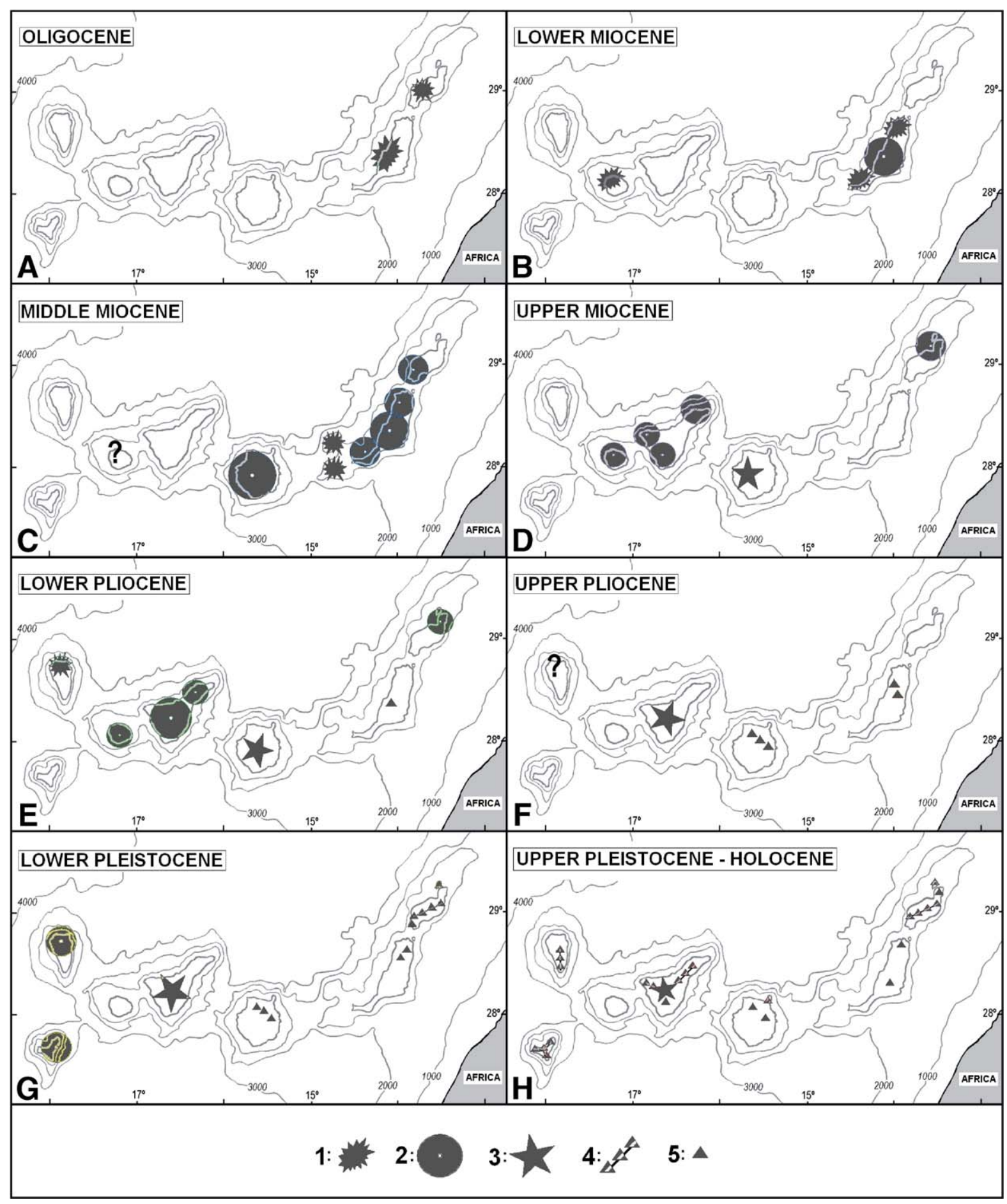

Fig. 11. Cartoon showing the temporary evolution of the volcanic activity in the Canary Archipelago. (1) Submarine edifices, (2) large basaltic edifices, (3) stratovolcanoes with frequent felsic materials, (4) ridge-shaped edifices, (5) disperse basaltic activity. Modified from Ancochea and Hernán (2004).

$7 \mathrm{Ma}$ ), shows only minor and dispersed activity. The large stratovolcano Roque Nublo develops on Gran Canaria covering the north and eastern sector of the older shield volcanoes (another example of eastwards shifting of the activity). The activity of the old edifices of Tenerife is restricted to the easternmost Anaga 
Edifice and yet a new later giant stratovolcano has already started its growth (Cañadas Edifice). With the construction of the Young Edifice, this concludes the volcanic activity of La Gomera. The beginning of the seamount construction of La Palma also marks this period (Staudigel et al., 1986).

The Upper Pliocene is characterised by the scarcity of basaltic magmatic production (Fig. 11F). The eastern ridge is only active in the central depression of Fuerteventura. After a new pause Plio-Quaternary emissions start and continue to very recent times in the northeastern half of Gran Canaria. As for Tenerife, very important and varied materials including abundant felsic flow and fall deposits accumulate in the Cañadas Edifice (Huertas et al., 2002). The seamount of La Palma probably maintained activity.

In the Lower Pleistocene (Fig. 11G), the activity on Gran Canaria, Fuerteventura and Tenerife remains the same as in the Upper Pliocene. The activity is restored in the area between the two old edifices of Lanzarote where abundant basaltic emission centres align along a $\mathrm{NE}-\mathrm{SW}$ trend so giving rise to a central ridge that is still active. The most outstanding event is the emergence of two new islands west of the very old and extinct island of La Gomera. The first one, La Palma, begins with the construction of its North Edifice, and then, just a very short time later, Hierro emerges south of the preceding island of La Palma (Fúster et al., 1993; Ancochea et al., 1994; Guillou et al., 1996; Balcells and Gómez, 1997; Guillou et al., 2001; Carracedo et al., 2001).

From the Upper Pleistocene up to present, the activity has not changed perceptibly (Fig. 11H). Lanzarote, Tenerife, La Palma and Hierro remain active, and Gran Canaria and Fuerteventura less so. Only La Gomera is absolutely extinct.

The spatial and temporal distribution of magmatism of La Gomera and Tenerife, as well as that of the whole archipelago does not follow a well-defined pattern. On the contrary, as even Guillou et al. (2004) admit the islands do not show "a clear west to east monotonous age progression". Other alternative models propose that the volcanic activity of the Canary Islands revives by processes repeatedly occurring over a period of time (i.e. Anguita and Hernán, 2000). These models are more consistent with the recorded ages than those proposing a single one-way migration of the initiation of the magmatism.

\section{Acknowledgements}

The Projects BTE2003-02153, CGL2004-02175, PR27/05-13868-BSCH and G.I:910469 UCM-CAM supported this work. The authors thank the reviewers, specially S. Day and the editor for their critical and fruitful comments. Prof. Allister Horbury revised the English version of the manuscript. This work was inspired and aimed by our colleague and friend Carmen Rosa Cubas who also collaborated with us. She was born in La Gomera and passed away in March 2003.

\section{References}

Abdel Monen, A., Watkins, N.D., Gast, P.W., 1971. Potassium-argon ages, volcanic stratigraphy, and geomagnetic polarity history of the Canary Islands: Lanzarote, Fuerteventura, Gran Canaria and La Gomera. Am. J. Sci. 271, 490-521.

Abdel-Monem, A., Watkins, N.D., Gast, P., 1972. Potassium-argon ages, volcanic stratigraphy and geomagnetic polarity history of the Canary Islands: Tenerife, La Palma and Hierro. Am. J. Sci. 272, 805-825.

Ancochea, E., Hernán, F., 2004. Canarias, rasgos generales. In: Vera, J.A. (Ed.), Geología de España. SGE-IGME, Madrid, pp. 637-642.

Ancochea, E., Huertas, M.J., 2003. Age and composition of the Amanay seamount, Canary Islands. Mar. Geophys. Res. 24, $161-169$.

Ancochea, E., Fúster, J.M., Ibarrola, E., Cendrero, A., Coello, J., Hernán, F., Cantagrel, J.M., Jamond, C., 1990. Volcanic evolution of the island of Tenerife (Canary Islands) in the light of new $\mathrm{K}-\mathrm{Ar}$ data. J. Volcanol. Geotherm. Res. 44, 231-249.

Ancochea, E., Hernán, F., Cendrero, A., Cantagrel, J.M., Fúster, J.M., Ibarrola, E., Coello, J., 1994. Constructive and destructive episodes in the building of a young oceanic island, La Palma, Canary Islands, and genesis of the Caldera de Taburiente. J. Volcanol. Geotherm. Res. 60, 243-262.

Ancochea, E., Brändle, J.L., Cubas, C.R., Hernán, F., Huertas, M.J., 1996. Volcanic complexes in the eastern ridge of the Canary Islands: the Miocene activity of the island of Fuerteventura. J. Volcanol. Geotherm. Res. 70, 183-204.

Ancochea, E., Huertas, M.J., Cantagrel, J.M., Coello, J., Fúster, J.M., Arnaud, N., Ibarrola, E., 1999. Evolution of the Cañadas edifice and its implications for the origin of the Cañadas Caldera (Tenerife Canary Islands). J. Volcanol. Geotherm. Res. 88, 177-199.

Ancochea, E., Brändle, J.L., Huertas, M.J., Cubas, C.R., Hernán, F., 2003. The felsic dikes of La Gomera (Canary Islands): identification of cone sheet and radial dike swarms. J. Volcanol. Geotherm. Res. 120, 197-206.

Anguita, F., Hernán, F., 1975. A propagating fracture model versus a hot spot origin for the Canary Islands. Earth Planet. Sci. Lett. 27, 11-19.

Anguita, F., Hernán, F., 2000. The Canary Islands origin: a unifying model. J. Volcanol. Geotherm. Res. 103, 1-26.

Araña, V., Ortiz, R., 1991. The Canary Islands: tectonic, magmatism and geodynamic framework. In: Kampunzu, A.B., Lubala, R.T. (Eds.), Magmatism in Extensional Structural Settings-The Phanerozoic African Plate. Springer, New York, pp. 209-249.

Balcells, R., Gómez, J.A., 1997. El Hierro: Memorias y mapas geológicos escala 1:25.000 (MAGNA). IGME. Madrid.

Bogaard, P.V.D., Schmincke, H.U., Freundt, A., Hall, C.M., York, D., 1988. Eruption ages and magma supply rates during the Miocene evolution of Gran Canaria. Naturwissenschaften 75, 616-617. 
Brändle, J.L., Cubas, C.R., Huertas, M.J., Hernán, F., Ancochea, E., 2001. Edad de los diques sálicos del Norte de la isla de La Gomera. Geogaceta 30, 179-181.

Bravo, T., 1964. Estudio geológico y petrográfico de la isla de La Gomera. Estud. Geol. 20, 1-56.

Cantagrel, J.M., Cendrero, A., Fúster, J.M., Ibarrola, E., Jamond, C., 1984. K-Ar chronology of the volcanic eruption in the Canarian Archipelago: Island of La Gomera. Bull. Volcanol. 47, 597-609.

Cantagrel, J.M., Arnaud, N.O., Ancochea, E., Fúster, J.M., Huertas, M.J., 1999. Repeated debris avalanches on Tenerife and genesis of Las Cañadas caldera wall (Canary Islands). Geology 27, 739-742.

Carracedo, J.C., 1975. Estudio paleomagnético de la Isla de Tenerife. Tesis Doctoral, Universidad Complutense de Madrid. 220 pp.

Carracedo, J.C., Day, S., Gillou, H., Rodríguez, E., Canas, J.A., Pérez, F.J., 1998. Hotspot volcanism close to a passive continental margin. Geol. Mag. 135, 591-604.

Carracedo, J.C., Badiola, E.R., Guillou, H., De La Nuez, J., PérezTorrado, F.J., 2001. Geology and volcanology of La Palma and El Hierro, western Canaries. Estud. Geol. 57, 175-273.

Cendrero, A., 1970. The volcano-plutonic complex of La Gomera (Canary Islands). Bull. Volcanol. 34, 537-561.

Cendrero, A., 1971. Estudio geológico y petrológico del Complejo Basal de la Isla de La Gomera (Islas Canarias). Estud. Geol. 27, $3-73$.

Coello, J., Cantagrel, J.M., Ibarrola, E., Jamond, C., Hernán, F., Fúster, J.M., Ancochea, E., Casquet, C., Díaz de Terán, J.R., Cendrero, A., 1992. Evolution of the eastern volcanic ridge of the Canary Islands, based on new K-Ar data. J. Volcanol. Geotherm. Res. 53, 251-274

Cubas, C.R., 1978a. Estudio de los domos sálicos de la isla de La Gomera (Islas Canarias): I. Vulcanología. Estud. Geol. 34, 53-70.

Cubas, C.R., 1978b. Estudio de los domos sálicos de la isla de La Gomera (Islas Canarias): II. Estud. Geol. 34, 107-128.

Cubas, C.R., Hernán, F., Ancochea, E., Brändle, J.L., Huertas, M.J., 1994. Serie Basáltica Antigua Inferior en el sector de Hermigua, Isla de la Gomera. Geogaceta 16, 15-18.

Cubas, C.R., Ancochea, E., Hernán, F., Huertas, M.J., Brändle, J.L., 2002. Edad de los domos sálicos de la isla de La Gomera. Geogaceta 32, 71-74.

Cueto, L.A., Barrera, J.L., Gómez, J.A., 1994. La caldera de hundimiento de Vallehermoso, Isla de La Gomera (Canarias). Bol. Geol. Min. 105-4, 7-12.

Dalrymple, G.B., Lanphere, M.A., 1969. Potassium-Argon Dating; Principles, Techniques and Applications to Geochronology. W.H. Freeman and Co, San Francisco. 258 pp.

De La Nuez, J., 1984. El Complejo Intrusivo Subvolcánico de la Caldera de Taburiente (La Palma, Canarias). Tesis Doctoral. Universidad Complutense de Madrid. 401 pp.

Feraud, G., 1981. Datation de réseaux de dykes et de roches volcaniques sousmarines par les méthodes $\mathrm{K}-\mathrm{Ar}$ et ${ }^{40} \mathrm{Ar}-{ }^{39} \mathrm{Ar}$. Utilisation des dykes comme marqueurs de paléocontraites. Thesis, Universidad de Nice. 146 pp.

Feraud, G., Giannerini, G., Campredon, R., Stillman, C.J., 1985. Geochronology of some Canarian dike swarms: contribution to the volcano-tectonic evolution of the archipelago. J. Volcanol. Geotherm. Res. 25, 29-52.

Fernández, C., Casillas, R., Ahijado, A., Perello, V., HernándezPacheco, A., 1997. Shear zones as result of intraplate tectonics in oceanic crust: an example of the Basal Complex of Fuerteventura (Canary Islands). J. Struct. Geol. 21, 1143-1149.
Funck, T., Schmincke, H.U., 1998. Growth and destruction of Gran Canaria deduced from seismic reflection and bathymetric data. J. Geophys. Res. 103, 15393-15407.

Fúster, J.M, Hernán, F., Cendrero, A., Coello, J., Cantagrel, J.M, Ancochea, E., Ibarrola, E., 1993. Geocronología de la isla de El Hierro (Islas Canarias). Bol. R. Soc. Esp. Hist. Nat., Secc. Geol. 88, 86-97.

Geldmacher, J., Hoernle, K., Bogaard, P.V.D., Zankl, G., GarbeSchönberg, D., 2001. Earlier history of the $\geq 70$-Ma-old Canary hotspot based on the temporal and geochemical evolution of the Selvagen Archipelago and neighboring seamounts in the eastern North Atlantic. J. Volcanol. Geotherm. Res. 111, 55-87.

Guillou, H., Carracedo, F.C, Pérez Torrado, F.J., Rodríguez Badiola, E., 1996. K-Ar ages and magnetic stratigraphy of a hotspotinduced, fast grown oceanic island: El Hierro, Canary Islands. J. Volcanol. Geotherm. Res. 73, 141-155.

Guillou, H., Carracedo, J.M., Duncan, R., 2001. K-Ar, ${ }^{40} \mathrm{Ar} /{ }^{39} \mathrm{Ar}$ ages and magnetostratigraphy of Brunhes and Matuyama lava sequences from La Palma Island. J. Volcanol. Geotherm. Res. 106, 175-194.

Guillou, H., Carracedo, J.C., Paris, R., Pérez Torrado, J., 2004. Implications for early shield-stage evolution of Tenerife from $\mathrm{K} / \mathrm{Ar}$ ages and magnetic stratigraphy. Earth Planet. Sci. Lett. 222, 599-614.

Hausen, H., 1971. Outlines of the geology of Gomera. Soc. Sci. Fen. Com. Phys. Mathem. 41, 1-53.

Hernán, F., Cubas, C.R., Brändle, M.J., Ancochea, J.L., 2000. Geometría del enjambre de diques cónicos de Vallehermoso. La Gomera (Islas Canarias). Geogaceta 27, 87-90.

Hoernle, K.A., Schmincke, H.U., 1993. The role of partial melting in the 15-Ma geochemical evolution of Gran Canaria: a blob model for the Canary hotspot. J. Petrol. 34, 599-626.

Huertas, M.J., Brändle, J.L., Ancochea, E., Hernán, F., Cubas, C.R., 2000. Distribución de los diques sálicos del Norte de La Gomera Geogaceta 27, 91-94.

Huertas, M.J., Ancochea, E., Cantagrel, J.M., Coello, J., Fúster, J.M., Ibarrola, E., 1994. Un episodio volcánico pre-Cañadas en la Isla de Tenerife. Geogaceta 15, 113-116.

Huertas, M.J., Arnaud, N.O., Ancochea, E., Cantagrel, J.M., Fúster, J. M., 2002. ${ }^{40} \mathrm{Ar} /{ }^{39} \mathrm{Ar}$ stratigraphy of main pyroclastic units from the Cañadas Volcanic Edifice (Tenerife, Canary Islands) and their bearing on the structural evolution. J. Volcanol. Geotherm. Res. $115,351-365$.

Ibarrola, E., Ancochea, E., Fúster, J.M., Cantagrel, J.M., Coello, J., Snelling, N.J., Huertas, M.J., 1993. Cronoestratigrafía del Macizo de Tigaiga: evolución de un sector del Edificio Cañadas (Tenerife, Islas Canarias). Bol. R. Soc. Esp. Hist. Nat., Geol. 88, 57-72.

Krastel, S., Schmincke, H.-U., Jacobs, C.L., Rihm, R., Le Bas, T.P., Alibés, B., 2001. Submarine landslides around the Canary Islands. J. Geophys. Res. 106, 3977-3998

Le Bas, M.J., Rex, D.C., Stillman, C.J., 1986. The early magmatic chronology of Fuerteventura. Geol. Mag. 123, 287-298.

Masson, D.G., Watts, A.B., Gee, M.J.R., Urgeles, R., Mitchell, N. C., Le Bas, T.P., Canals, M., 2002. Slope failures on the flanks of the western Canary Islands. Earth-Sci. Rev. 57, 1-35.

McDougall, I., Schmincke, H.U., 1976. Geochronology of Gran Canaria, Canary Islands: age of shield building volcanism and other magmatic phases. Bull. Volcanol. 40, 57-77.

Morgan, W.J., 1971. Convection plumes in the lower mantle. Nature 230, 42-43.

Muñoz, M., Sagredo, J., 2004. El Complejo Basal de Fuerteventura. In: Vera, J.A. (Ed.), Geología de España. SGE-IGME, Madrid, pp. 645-649. 
Muñoz, M., Sagredo, J., Rincón-Calero, P.J., Vegas, R., 1997. Emplazamiento en una zona de cizalla dúctil-frágil transtensiva para el plutón de Pájara, Fuerteventura, Islas Canarias. Geogaceta 21, 171-174.

Paris, R., Guillou, H., Carracedo, J.C., Pérez Torrado, F.J., 2005. Volcanic and morphological evolution of La Gomera (Canary Islands), based on new $\mathrm{K}-\mathrm{Ar}$ ages and magnetic stratigraphy: implications for oceanic island evolution. J. Geol. Soc. (Lond.) $162,501-512$.

Peterson, D.W., Moore, R.B., 1987. Geologic history and evolution of geologic concepts, island of Hawaii. In: Volcanism in Hawaii. Prof. Pap.-Geol. Surv. (U.S.) 1350, 149-189.

Robertson, A.H.F., Bernouilli, D., 1982. Stratigraphy, facies and significance of Late Mesozoic and Early Tertiary sedimentary rocks of Fuerteventura (Canary Islands) and Maio (Cape Verde Islands). In: Rad, U. Von, Hinz, K., Sarnthein, M., Seibold, E. (Eds.), Geology of the Northwest African Continental Margin, pp. $498-525$.

Rodríguez Losada, J.A., 1987. Un complejo de diques cónicos en la isla de La Gomera, Islas Canarias. Estud. Geol. 43, 41-45.

Rodríguez Losada, J.A., 1988. El Complejo Traquítico-Fonolítico de La Gomera. Tesis Doctoral. Universidad Complutense de Madrid. $414 \mathrm{pp}$.

Rodríguez Losada, J.A., Martínez Frías, J., 2004. The felsic complex of the Vallehermoso Caldera: interior of an ancient volcanic system (La Gomera Canary Islands). J. Volcanol. Geotherm. Res. 137, 261-284.

Sánchez Guzmán, J., Abad, J., 1986. Sondeo geotérmico Lanzarote: 1. Significado geológico y geotérmico. An. Fís., Ser. B 102-109 (especial).

Schmincke, H.U., Sumita, M., 1998. Volcanic evolution of Gran Canaria reconstructed from aprom sediments. Synthesis VICAP drilling project (ODP Leg 157). In: Weaver, P.P.E., Schmincke, H.U., Firth, J.V., Duffield, W. (Eds.), Proc. ODP, Sci. Results, vol. 157. Ocean Drilling Program, College Station, TX, pp. 443-469.

Staudigel, H., Schmincke, H.U., 1984. The Pliocene seamount series of La Palma (Canary Islands). J. Geophys. Res. 89, 11195-11215.

Staudigel, H., Feraud, G., Giannerini, G., 1986. The history of intrusive activity on the island of La Palma (Canary Islands). J. Volcanol. Geotherm. Res. 27, 299-322.

Steiger, R.H., Jaeger, E., 1977. Subcommision of geochronology: of the use of decay constants in geo and cosmochronology. Earth Planet. Sci. Lett. 36, 359-362.

Stillman, C.J., 1999. Giant Miocene landslides and the evolution of Fuerteventura, Canary Islands. J. Volcanol. Geotherm. Res. 94, 89-104.

Stillman, C.J., Fúster, J.M., Bennell-Baker, M.J., Muñoz, M., Smewing, J.D., Sagredo, J., 1975. Basal Complex of Fuerteventura is an oceanic intrusive complex with rift-system affinities. Nature 257, 469-471.

Thirlwall, M.F., Singer, B.S., Marriner, G.F., 2000. ${ }^{39} \mathrm{Ar}-{ }^{40} \mathrm{Ar}$ ages and geochemistry of the basaltic shield stage of Tenerife, Canary Islands, Spain. J. Volcanol. Geotherm. Res. 103, 247-297.

Walter, T.R., Schmincke, H.U., 2002. Rifting, recurrent landsliding and Miocene structural reorganization on NW-Tenerife (Canary Islands). Int. J. Earth Sci. 91, 615-628.

Watts, A.B., Masson, D.G., 1995. A giant landslide on the north flank of Tenerife, Canary Islands. J. Geophys. Res. 100 (B12), 24487-24498.

Wilson, J.T., 1973. A possible origin of the Hawaiian Islands. Can. J. Phys. 41, 863-870. 